\title{
A multi-technique approach to determine temporal and spatial variability of groundwater- stream water exchange
}

Running title: Characterization of groundwater-stream exchange processes

\author{
Kasimcan Koruk ${ }^{1}$, Koray Kamil Yilmaz ${ }^{\text {* }}$, Zuhal Akyurek ${ }^{2}$, Andrew Binley ${ }^{3}$ \\ ${ }^{1}$ Department of Geological Engineering, Middle East Technical University, Ankara, Turkey \\ ${ }^{2}$ Department of Civil Engineering, Middle East Technical University, Ankara, Turkey \\ ${ }^{3}$ Lancaster Environment Centre, Lancaster University, Lancaster, United Kingdom \\ *Corresponding Author: \\ Email: yilmazk@metu.edu.tr
}

\section{Acknowledgements}

This study was funded by TUBITAK (The Scientific and Technological Research Council of Turkey) in the scope of research and development project 115Y041 and fieldworks were performed in cooperation with the General Directorate of State Hydraulic Works, Turkey. The authors would like to thank Çağrı Hasan Karaman, Denis Denizhan Yanmaz, and The General Directorate of State Hydraulic Works personnel for their support and assistance in the fieldworks. 


\section{Abstract}

5 Characterizing the spatio-temporal distribution of groundwater-surface water exchange fluxes is of 6 paramount importance in understanding catchment behavior. A wide range of field-based techniques are 7 available for such characterization. The objective of this study is to quantify the spatio-temporal distribution 8 of the exchange fluxes along the Çakit stream (Nigde, Turkey) through coupling a set of geophysical 9 techniques and in-stream measurements in a hierarchical manner. First, geological and water quality 10 information were combined at the catchment scale to determine key areas for reach-scale focus. Second, 11 electromagnetic induction (EMI) surveys were conducted along the reach to pinpoint potential groundwater 12 upwelling locations. EMI anomalies guided our focus to a 665 meter-long reach of the stream. Along this 13 selected reach, a fiber-optic distributed temperature sensing (FO-DTS) system was utilized to investigate 14 streambed-temperature profiles at fine spatial and temporal scales. Furthermore, vertical hydraulic gradients 15 and exchange fluxes were investigated using nested piezometers and vertical temperature profiles, 16 respectively, at two potential upwelling locations and a potential downwelling location identified by 17 previous surveys. The results of the study reveal heterogeneity of vertical water-flow components with 18 seasonal variability. The EMI survey was successful in identifying a localized groundwater upwelling 19 location. FO-DTS measurements revealed a warm temperature anomaly during cold air temperature and 20 low streamflow conditions at the same upwelling site. Our point-based methods, namely vertical 21 temperature profiles and vertical hydraulic gradient estimates, however, did not always provide consistent 22 results with each other and with EMI and DTS measurements. This study, therefore, highlights the 23 opportunities and challenges in incorporating multi-scale observations in a hierarchical manner in 24 characterization of the groundwater-surface water exchange processes that are known to be highly 25 heterogeneous in time and space. Overall, a combination of different methods helps to overcome the 26 limitations of each single method and increases confidence in the obtained results.

27 Key words: Groundwater - Surface water interaction, Electromagnetic Induction, Distributed 28 Temperature Sensing, Streambed Temperature Profile, Hydrogeophysics, Hierarchical Approach, 29 Thermochrons, Exchange Processes 


\section{Introduction}

Surface water and groundwater are interconnected at multiple spatio-temporal scales (Winter et al., 1998). As such, quantification of groundwater - surface water (GW-SW) exchange fluxes is a prerequisite for studies focusing on basin scale water management, water quality and ecological status of water bodies (Sophocleous, 2002; Winter et al., 1998). However, exchange processes often exist with significant heterogeneity in space and time, hence appropriate methods are required that are sensitive to the scale of interest (e.g., Kalbus et al., 2006; Binley et al., 2013; Kennedy et al., 2009; Sophocleous, 2002; Varli and Yilmaz, 2018). Several studies have been performed and new methods and technologies have been adopted to determine GW-SW interaction. Hydraulic head measurements and Darcian flux estimates, differential streamflow discharge measurements, seepage meters, environmental tracers, monitoring of water-quality parameters and geophysical applications are some of widely used methods to determine the GW-SW interaction (e.g., Rosenberry and LaBaugh, 2008; Brodie et al., 2007; Kalbus et al., 2006).

At the point scale, hydraulic head measurements from nested piezometers which are installed at two different streambed depths can be used to calculate vertical hydraulic gradients in the streambed (Conant, 2004). From two or more piezometers installed at the same depth but at different locations, lateral or horizontal hydraulic gradient can be estimated (Kalbus et al., 2006). Temperature is also commonly used as a tracer to determine groundwater-surface water interaction, exploiting the difference between the temperature of groundwater and surface water on daily and seasonal temporal scales (Anderson, 2005). The idea of using temperature as a tracer emerged in the 1960s: the study of Suzuki (1960) focused on predicting water flux through saturated sediments using an analytical solution to the heat flow equation. Studies of Stallman (1963) and Bredehoeft and Papaopulos (1965) followed with modifications to Suzuki's original approach. Lapham (1989) used streambed temperature measurements to quantify vertical groundwater flow. Recently, new analytical and numerical methods have been developed based on the temperature time series records (Hatch et al., 2006; Keery et al., 2007). Hatch et al., (2006) offered 1-dimensional analytical solution to obtain vertical fluid flux from temperature time series obtained from two different depths of streambed. Gordon et al., (2013) employed iButton temperature sensors embedded in steel rods to record vertical temperature profile of the streambed; they obtained vertical water flow velocity from vertical temperature profiles using the VFLUX computer program (Gordon et al., 2012). Although these new methods appear to offer reliable results, they operate at a local scale and thus require many measurements in order to quantify the exchange between groundwater and stream water along a reach (Brodie et al., 2007).

While temperature-based methods, described above, provide temperature measurements at the point scale, Selker et al. (2006a,b) introduced and first applied fiber optic distributed temperature sensing (FO-DTS) technology in the field of hydrology, revealing how measurements can be performed in both time and space. 
64 FO-DTS is based on the detection of reactions against temperature anomalies (Raman backscattering) of a 65 light source transmitted through a fiber optic cable (Dakin, 1987). Under appropriate surface watergroundwater temperature contrast, a fiber-optic cable installed along a streambed can reveal thermal anomalies at locations where groundwater upwelling occurs. Many studies have followed the guidance of Selker et al. (2006a) and offered calibration techniques and methods to apply FO-DTS (Hausner et al., 2011; Krause et al., 2012; Matheswaran et al., 2014; Van de Giesen et al., 2012).

Geophysical methods have been employed in the field of hydrology at a wide variety of vertical and horizontal survey scales (Binley et al., 2015). Crook et al. (2008) illustrates the use of electrical resistivity imaging for groundwater-surface water exchange studies: variation in electrical conductivity in the streambed may reveal heterogeneity of the streambed architecture, or fluids within them. In relatively small, shallow streams such a method is challenging to use because of the need to install electrodes. The electromagnetic induction (EMI) technique is a more practical method for detecting local shallow heterogeneities beneath surface water bodies in a continuous manner and hence is being increasingly applied in the field of hydrology (Binley et al., 2013; Rejiba et al., 2018; Gaona et al., 2019). EMI surveys provide an integrated measure of the apparent electrical conductivity over a depth that is a function of the separation between transmitter and receiver coils. These measurements allow the estimation of the electrical conductivity of the streambed sediments through simultaneous measurement of the surface water's depth and conductivity as well as the knowledge of the signal sensitivity function of the sensor (Monsoor et al., 2006; Binley et al., 2013). Similar to the electrical resistivity method, EMI can give broad information on textural variability of the streambed and also reveal contrasts in pore water ionic composition (Binley et al., 2013).

Whilst each method can be used to quantify certain aspects of the groundwater-surface water interaction processes, recent studies have combined various methods at multiple scales to more effectively characterize these processes that are known to be highly heterogeneous in space and time (Frederiksen et al., 2018; Varli and Yilmaz, 2018; González-Pinzón et al., 2015; Klos et al., 2015; Kalbus et al., 2006). For example, Rosenberry et al. (2016) combined physical (seepage meters, wells, piezometers), thermal (FO-DTS, infrared, vertical temperature profiles) and geophysical methods (EMI) to characterize the distribution of dwarf wedgemussles along upper reaches of the Delaware River. More recently, Gaona et al. (2019) revealed how combining FO-DTS and EMI can provide strong insight into groundwater-surface water exchange processes along a $50 \mathrm{~m}$ reach. In this study we reveal how these methods can be combined effectively at larger scales.

The objective of this study is to quantify the spatio-temporal distribution of the exchange fluxes along the Çakıt stream (Nigde, Turkey) through coupling a set of geophysical techniques and in-stream measurements 
97 in a hierarchical manner. First, a two kilometer-long stream reach with potential groundwater input was 98 determined from the results of basin scale major ion chemistry, geological information and 99 geomorphological observations. Secondly, geophysical surveys including EMI and FO-DTS surveys were 100 conducted at the reach scale to pinpoint potential localized groundwater upwelling sections along the 101 streambed. Vertical hydraulic gradients and exchange fluxes were investigated using nested piezometers 102 and vertical temperature profiles, respectively, to support the results obtained from the geophysical surveys.

103

104 105 106 107 108 109 110 111 112 113 114 115 116 117 118 119 120 121 122 123 124 125 126 127 128

\section{Study Area}

The study basin covers an area of $529 \mathrm{~km}^{2}$ in Nigde province, south of Turkey (Figure 1). The basin is characterized by highlands with many steep slopes. The Bolkar Mountains are located to the south of the basin reaching up to $3450 \mathrm{~m}$ above sea level (a.s.1.) within the basin boundaries. Meteorological data are available from a meteorological station located at $1453 \mathrm{~m}$ a.s.1., in the west part of the basin that is operated by the General Directorate of Meteorology since 1937. Mean monthly air temperature (1937-2017) ranges from $-1.8^{\circ} \mathrm{C}$ (January) to $21.6^{\circ} \mathrm{C}$ (July), with measured minimum and maximum air temperature values of $-21.5{ }^{\circ} \mathrm{C}$ (in February) and $37.5^{\circ} \mathrm{C}$ (in July). Mean annual precipitation is $343 \mathrm{~mm}$. Mean monthly precipitation ranges from $51.2 \mathrm{~mm}$ in May to $7.3 \mathrm{~mm}$ in August.

Çakit stream is the main stream in the basin and starts from western hills of the basin and discharges to the east, where it joins the Alihoca stream. There are three stream gauging stations (SGS) within the basin. The upstream gauging station is located on the Darbogaz stream which begins at the confluence point of Kilan and Ganimet streams; the other two SGSs are located at the downstream of the basin at Alihoca and Çakit stream branches (Figure 1a). The stream name changes to Darbogaz stream after the Darbogaz SGS and joins to upper Çakıt stream. Three SGSs have been in operation since October, 2016. Summer baseflow conditions usually occur from July to October within the basin. Average baseflow discharge measured at Darbogaz SGS was $0.017 \mathrm{~m}^{3} / \mathrm{sec}$ in 2018 . The upper Çakit stream is dry during July to October. Average baseflow discharge at Alihoca SGS and Çakıt SGS, which are located at the downstream end of the basin, are $0.113 \mathrm{~m}^{3} / \mathrm{sec}$ and $0.180 \mathrm{~m}^{3} / \mathrm{sec}$, respectively. Stream discharge at Darbogaz increases at the confluence of the Ganimet stream and Kilan stream. The streams are fed by snowmelt during spring. Snowmelt originating from southern hillslopes is a strong controlling factor on the high discharge in Darbogaz during spring. The average stream channel width of the Çakıt stream is 3.5-4.0 meters, which is controlled by topography.

Shelf and ophiolites are the predominant geological environments over the basin (Figure 1b). Volcanic deposits are the result of volcanism starting from Middle Miocene; they were deposited together with terrestrial-alluvial deposits and lacustrine deposits. Geological units exposed over the area are Permian- 
129 Jurassic aged Marble and Olistostrome in the south, Upper Cretaceous Ophiolithic Mélange in the form of 130 Nappe, Paleocene intercalated clastics-limestone, Eocene limestone, Oligocene clastics, Oligocene, 131 Miocene aged Gypsum and evaporites, Eocene-Miocene aged volcanic deposits, and Quaternary-aged 132 moraine, travertines, alluvial cones, and alluvium. Gypsum units are exposed over the surface overlaying 133 from the west to middle parts of the basin, and they affect the hydrochemical properties of the basin. 134 Alluvium units are generally composed of poorly rounded gravel, sand and silt with mud-clay lenses; they 135 show unconfined aquifer properties with thicknesses up to 30-40 meters. The main groundwater bearing 136 units are alluviums, alluvial cones, travertines and limestone units located in the west of the study area, 137 marble and moraine units located in the south of the study area (State Hydraulic Works, 2014).

\section{Figure 1 here.}

\section{Methods}

141 The objective of this study is to quantify the spatio-temporal distribution of the groundwater-stream 142 exchange fluxes along the Çakıt stream through coupling a set of geophysical techniques and in-stream 143 measurements in a hierarchical manner. First, geological, geomorphological and water quality information 144 (Figure 1b) were combined at the catchment scale to determine key areas for reach-scale focus. Major ion 145 analyses were conducted at 27 sampling locations in June-2016 to describe the hydrochemical 146 characteristics of the surface waters in the basin and their possible relation to geology and exchange fluxes.

147 Basin scale analyses were followed by geophysical surveys including EMI and FO-DTS surveys to 148 investigate potential groundwater upwelling sections at the reach scale. Furthermore, vertical hydraulic 149 gradients and exchange fluxes were investigated using nested piezometers and vertical temperature profiles, 150 respectively, at two potential upwelling locations and a potential downwelling location identified by 151 previous surveys.

152 3.1. Electromagnetic Induction Survey

153 EMI surveys can be used to determine the apparent electrical conductivity of the subsurface. The method is 154 based on the generation of a primary electromagnetic field from a transmitter coil, and the measurement of 155 a secondary field at a receiver coil, which is affected by the conductivity of the subsurface (McNeil, 1980). 156 The depth of investigation is a function of frequency of the induced field and distance between a transmitter 157 and a receiver coils (McNeill, 1980). In-stream measurements can be carried out by placing the device above 158 the water surface (e.g. in an inflatable vessel). With such a configuration, the apparent electrical 159 conductivity is thus a function of the depth of the water column, its electrical conductivity and the bulk 160 electrical conductivity of the streambed sediment. Given measurements of stream depth and stream water 
161

162

163

164

165

166

167

168

169

170

171

172

173

174

175

176

177

178

179

180

181

182

183

184

185

186

187

188

189

190

electrical conductivity, their effects can be removed from the apparent electrical conductivity (e.g. Binley et al., 2013). Variations in electrical conductivity can then be attributed to variations in texture of the river bed sediments and/or pore water electrical conductivity (Binley et al., 2013). Under these assumptions, high permeability/porosity locations along the streambed inferred by EMI surveys could pinpoint locations of potential groundwater upwelling, or contrasts in pore water electrical conductivity can indicate localized groundwater sources.

EMI measurements were made with the CMD-1 probe (GF Instruments, Czech Republic), in vertical coplanar orientation, giving an effective depth of 1.5 meters. Note that we specifically targeted shallow EMI measurements to explore the streambed sediments. The positions of EMI measurements were recorded simultaneously using a SATLAB-SLC GPS receiver (Satlab Geosolutions AB, Sweden), and water depth was measured with an Onset HOBO U20-001-01 water level data logger which was dragged along the streambed. The EC of stream water was measured with EXTECH pH100 pH/conductivity probe.

\subsection{Fiber-Optic Distributed Temperature Sensing Technology}

A XT-DTS ${ }^{\mathrm{TM}}$ (Silixa, United Kingdom) FO-DTS unit was employed for this study, enabling a sampling resolution of $25 \mathrm{~cm}$ over a measurement range of up to $10 \mathrm{~km}$ with a $0.01{ }^{\circ} \mathrm{C}$ temperature resolution. A 1$\mathrm{km}$ long single steel wall tube armored fiber optic duplex cable (Silixa, United Kingdom) was employed together with the XT-DTS ${ }^{\text {TM }}$. FO-DTS measurements were performed during June, September and October 2018 field campaigns. Data were collected for 30 minute periods, each period representing different time intervals in a day (see Section 4.3 for details). Measurements were taken at each $0.254 \mathrm{~m}$ increment continuously for approximately 30 minutes. As each measurement lasted 23 seconds with the XT-DTSTM, a total of about 80 measurements were made for each 30 minute interval. A double-ended calibration method (Van de Giesen et al., 2012) was adopted for the study. Two calibration baths, one hot and one cold, were located near the FO-DTS unit. 10-meter long sections of the fiber-optic cable were submerged into calibration baths, so that approximately 40 measurements were recorded for each calibration bath considering spatial resolution of $0.254 \mathrm{~m}$. Temperatures of the calibration baths were traced using Pt100 temperature calibration probes (accuracy better than $\pm 0.1^{\circ} \mathrm{C}$ within temperature range $-50^{\circ} \mathrm{C}$ to $+250^{\circ} \mathrm{C}$ ) which were provided together with the FO-DTS unit. A battery-powered aquarium pump was used in the calibration baths to prevent thermal stratification. Cobbles were laid on cable to maintain the connection between streambed and cable at every few meters/where necessary. Burying the cable in the streambed was not possible due to presence of pebbles, and cobbles. 
191

192

193

194

195

196

197

198

199

200

201

202

203

204

205

206

207

208

209

210

211

212

\subsection{Nested Piezometers and Vertical Hydraulic Gradient Estimation}

Piezometers consisting of high density polyethylene (HDPE) pipes having a $32 \mathrm{~mm}$ outer diameter and 2.6 $\mathrm{mm}$ wall thickness were fabricated with a screen length of $20 \mathrm{~cm}$. Screens were made by cutting slots in the piezometers rather than drilling holes in an effort to have greater connectivity and to minimize clogging. Piezometer bottoms were plugged with plastic pipe caps to prevent vertical flow. For installation of piezometers, a mechanical installation method, similar to that described by Baxter et al. (2003) was followed. The installation unit consisted of a metal pointed inner drive rod and an outer metal tube that prevented collapse of the opening during removal of the drive rod (Figure 2). On the top of these two units, caps were welded to bear hammer blows. Holes on the sides of these caps enabled the use of an iron bar to take the units out of the sediments. Piezometers were installed first by driving the inner drive rod and outer metal tube together into the streambed sediments. The inner drive rod is then removed and HDPE piezometers were inserted in their place. In the final step, the outer metal tube was removed.

\section{Figure 2 here.}

Six piezometers were installed within the streambed at 3 different sites, namely P1, P2 and P3 (see Section 4.4 for locations). Two of the piezometer sites coincide with locations of high apparent electrical conductivity anomalies (from EMI) in the upstream section; the third site is situated at the downstream end of the study site with low to intermediate EMI measured electrical conductivity values. The piezometers at each site were nested, consisting of one shallow and one deep piezometer. The shallow piezometers were installed at depths that ranged between $36 \mathrm{~cm}$ and $43 \mathrm{~cm}$, whereas the deep piezometers were installed at depths that ranged between $85 \mathrm{~cm}$ and $102 \mathrm{~cm}$. Note that many studies that measure vertical hydraulic gradients in streams do not use nested piezometers - typically head from only one piezometer is compared with the surface-water stage to determine a vertical hydraulic gradient. However, having nested piezometers at each location helps to check the consistency of the results.

Piezometers P1, P2 and P3 were installed on 27-June, 28-June and 18-September-2018, respectively. Shallow and deep piezometers are denoted by "S" and "D", respectively (for example, P1-D denotes deep piezometer at site 1). Water levels were measured manually in piezometers P1 and P2 between 28-June and 7-November-2018, and in piezometers P3 between 19-September and 7-November-2018 using a Solinst巴 Model 107 TLC meter (Solinst Canada Ltd., Georgetown, Ont., Canada). Piezometers were purged prior to manual water level measurements to ensure hydraulic connection (no clogging) and measurements were made after water levels were stabilized. Surface water stage was also measured manually at the piezometer sites. Water level fluctuations in piezometers P2 and P3 were monitored continuously with a 10-minute logging interval for the period 27-October-2018 to -7-November-2018 using $\mathrm{HOBO}^{\circledR} \mathrm{U}_{20-001-01}$ pressure 
223 loggers (Onset Corporation, USA). A pressure transducer was deployed on the streambed at site P2 to 224 continuously monitor the surface water stage during this time period.

225 Hydraulic head measurements from nested piezometers and surface water stage were used to calculate 226 vertical hydraulic gradient (VHG) values, and hence the direction of streambed vertical flux at the point 227 scale. Negative VHG values indicate upwelling flux direction while positive values indicate a downwelling 228 flux direction.

\section{3.4. Vertical Flux Determination from Vertical Temperature Profiles}

230 Vertical water flux through the streambed were estimated from diurnal variations in streambed vertical 231 temperature profiles. 1-Wire iButton Temperature loggers (Maxim Integrated ${ }^{\circledR}$ DS1922L) having 0.0625 ${ }^{\circ} \mathrm{C}$ resolution, $0.5^{\circ} \mathrm{C}$ accuracy at $-10^{\circ} \mathrm{C}$ to $65^{\circ} \mathrm{C}$ temperature range were used. iButtons were water-proofed with PLASTI DIP ${ }^{\circledR}$ rubber coating and embedded on wooden dowels at two different configurations (Figure 3). Initially a configuration with two iButtons (Figure 3a) was used at sites P1 and P2 in June 2018. However, due to failure of one iButton at site P2, flux calculation was not possible for this site in June. To avoid such a failure in further campaigns, we optionally included a 3-iButton configuration where deemed necessary. iButtons were shielded with metal washers to ensure proper thermal conductivity with the streambed. They were set to record the temperature every 10 minutes to make sure that the diurnal temperature variation was properly captured. iButton temperature profiles were recorded in three different sites (P1, P2 and P3) with time periods ranging from 5 to 16 days.

\section{Figure 3 here.}

242 Vertical water fluxes were estimated using VFLUX program - a vertical fluid heat transport solver (Gordon 243 et al., 2012) based on the Hatch et al. (2006) amplitude method. Typical values of sediment and water 244 thermal properties suggested by the program developers were used; thermal dispersivity $(0.001 \mathrm{~m})$, thermal 245 conductivity $\left(0.0045 \mathrm{cal} /\left(\mathrm{s}^{\cdot} \mathrm{cm} \cdot{ }^{\circ} \mathrm{C}\right)\right)$, volumetric heat capacity of the water $\left(1.0 \mathrm{cal} /\left(\mathrm{cm}^{3 \cdot{ }^{\circ}} \mathrm{C}\right)\right)$, volumetric 246 heat capacity of the sediments $\left(0.5 \mathrm{cal} /\left(\mathrm{cm}^{3 .}{ }^{\circ} \mathrm{C}\right)\right)$ and total porosity $(0.28)$.

\section{4. Results}

248 4.1. Determination of the Location of the Reach-Scale Study Area

249 Major ion analysis performed at the basin scale is illustrated in a Piper diagram (Figure 4) and fluid electrical 250 conductivity (EC) values at the sampling locations are provided on the geology map (Figure 1b). Note that 251 the samples are arranged according to river branches from upstream towards downstream (Figure 1a). 
Figure 4 here.

The upper Çakıt stream branch has the highest total dissolved solids, specifically attributed to the gypsum units $\left(\mathrm{CaSO}_{4} 2 \mathrm{H}_{2} \mathrm{O}\right)$ dissolving high concentrations of sulfate and calcium. In contrast, the Alihoca stream branch shows the lowest total dissolved solids with higher concentrations of bicarbonate and calcium compared to other ions measured along this branch. Similar to the Alihoca branch, the Ganimet and Darboğaz stream branches are also characterized by low total dissolved solids. The upper Çakıt stream branch becomes slightly diluted towards downstream due to tributaries draining volcanic deposits to the north. The upper Çakıt stream branch and Darboğaz branches merge immediately downstream of sampling locations 4 and 11 (Figure 1), respectively, to form the Çakıt stream, reflecting mixed ion concentrations. Along the Çakıt stream, sulfate and carbonate concentration increase from sampling location 13 to 14 due to a confluence with a tributary draining gypsum unit. The confluence with a northerly tributary before sampling location 15 further increases ion concentrations, specifically sodium, sulfate and chloride. According to the Piper diagram shown in Figure 4, the hydrochemical facies of upper Çakıt and downstream parts of Çakıt are calcium-sulfate type, whereas the Ganimet, Darboğaz, Kılan and upstream part of the Çakıt stream branches are calcium-bicarbonate type waters. Low total dissolved solids concentrations in the Alihoca, Ganimet and Darboğaz stream branches together with steep stream gradients were interpreted as the sign of less groundwater influx potential. The discharge in the upper Çakit is significantly low and the stream is not accessible due to steep valley sides and relatively steep streambed slopes. Moreover, the downstream part of the Çakıt is also characterized by steep valley sides and relatively steep streambed slopes.

Considering the results of the major ion analysis, high amount of alluvium deposits, gentle streambed slopes, accessibility and the information obtained from local water users (indicating groundwater contribution to the stream along the reach) a 2-km reach in the upstream part of the Çakıt stream, situated between sampling locations 12 and 14, was selected as the study reach (Figure 1) where groundwater-surface water exchange processes was to be further investigated. Individual manual discharge measurements at the study reach on 2-July-2018 and 11-July-2018 were done in order to understand the water balance of the study reach. On 2July-2018 discharge observed at Darbogaz SGS was $0.210 \mathrm{~m}^{3} / \mathrm{sec}$. At this time, the upper Çakıt stream was dry, and discharge at P2 and P1 (installed piezometers explained in section 3.3) was $0.358 \mathrm{~m}^{3} / \mathrm{sec}$ and 0.378 $\mathrm{m}^{3} / \mathrm{sec}$. On 11-July-2018 discharge observed at Darbogaz SGS was $0.103 \mathrm{~m}^{3} / \mathrm{sec}$, the upper Çakıt stream was dry, and discharge at $\mathrm{P} 2$ and $\mathrm{P} 1$ was $0.325 \mathrm{~m}^{3} / \mathrm{sec}$ and $0.301 \mathrm{~m}^{3} / \mathrm{sec}$, respectively.

\subsection{Electromagnetic Induction Survey}

The first EMI survey was performed along the 2-km reach identified in Section 4.1 on 31-January-2018 (Figure 5). Note that the entire reach shown in Figure 5 is equivalent to the reach indicated in red in Figure 
285 1a, and the stream reach within the rectangle in Figure 5 is equivalent to the study reach shown in Figure 286 6a. A major conductive anomaly was detected during this reconnaissance survey. To further investigate this 287 anomaly location together with locations without anomalies in an affordable manner, a $665 \mathrm{~m}$ reach was 288 selected as the study area for investigation of groundwater and surface water interaction processes in a more 289 detailed manner using other methods (Figure 6). A second EMI survey was conducted on 27-June-2018 290 along this more focused study area. The depth of stream water ranged from 0 to $80 \mathrm{~cm}$ (mean value of 29.3 $291 \mathrm{~cm}$ ) along the reach during the EMI survey; the electrical conductivity of the stream water was $894 \mu \mathrm{S} / \mathrm{cm}$. 292 EMI surveys were repeated in September and October-2018 and revealed the same anomaly pattern 293 observed in June- 2018. Note that a barrier was constructed by local residents at the middle of stream reach 294 to divert the water for irrigational purposes. Such a barrier may have an effect on the hydrological 295 characteristic of the reach, as discussed later.

296 Figure 5 here.

$297 \quad$ Figure 6 here.

\section{4.3. Fiber-Optic Distributed Temperature Sensing}

299 Table 1 lists the DTS measurement periods, minimum, mean and maximum values of the measured top-of300 streambed temperatures, together with air temperature data collected from the nearest meteorological 301 station, and daily stream discharge values collected from the Çakıt stream gauging station. It can be seen 302 that there is a marked difference in air temperature on measurement period of October compared to June 303 and September measurement periods. Moreover, stream discharge is also relatively lower in October than 304 the values in June and September.

\section{Table 1 here.}

306 Figure 7 shows the FO-DTS measurements taken on 18-September-2018 13:28-13:53 and on 26-October3072018 07:31-08:02. Focusing on Figure 7b it can be seen that the top-of-the-streambed temperature values 308 increases with time (x-axis) indicating warming of stream water in response to increasing air temperature 309 (Figure 7a). More importantly, however, temperature values along the transect (y-axis) are highly variable 310 with a marked decrease at the pooled upstream part of the barrier due possibly to increase in stage, and a 311 marked increase at the downstream of the barrier $(325-328 \mathrm{~m}$; the location of the barrier is shown in Figure 312 6) due possibly to the surface heating of the pooled water behind the barrier. High variability in temperature 313 along the transect (Figure $7 \mathrm{~b}$ and $7 \mathrm{c}$ ) is possibly due to the marked solar radiation and vegetation shading 314 effects. With groundwater temperature values at around $14^{\circ} \mathrm{C}$ (based on piezometer measurements), possible 315 groundwater inflow from the streambed would be indicated by sustained cold temperatures along the $\mathrm{x}$-axis. 316 However, FO-DTS measurements did not indicate any variation in the temperature along the streambed that 
317 could be attributed to groundwater inflow in the June and September 2018 field campaigns. Shading effects, 318 stream water temperature values being close to the groundwater temperature values and high discharge 319 conditions (turbulence) result in unfavorable conditions for the detection of groundwater inflow using FO320 DTS measurements (Table 1). Moreover, in the presence of relatively coarse-grained streambed sediments, 321 the fiber optic cable could not be buried into the streambed. This situation presented another unfavorable 322 condition that is known to result in difficulty in detecting thermal anomalies unless groundwater inflow is 323 significant (Tristram et al. 2015; Lowry et al. 2007).

324 FO-DTS measurements on 26-October-2018 (Figure 7d-f) were taken early in the morning (7:31am$3258: 00 \mathrm{am})$ under cold $\left(3^{\circ} \mathrm{C}\right.$ air temperature $)$ and cloudy weather conditions hence resulting in minimal shading 326 effect and marked differences in stream water and groundwater temperatures. Moreover, stream discharge 327 was also lower compared to the observed values in September field campaign. Locations with groundwater 328 inflows would be indicated by sustained warmer temperatures along the $\mathrm{x}$-axis in Figure 7e, and warm 329 anomalies in mean temperatures (Figure 7f). This situation is observed at a distance of around 550m along 330 the transect, close to piezometers $\mathrm{P} 2$ and P3 indicating groundwater inflow at this location detected by the 331 FO-DTS measurements. Figure $7 f$ also shows that the stream water temperature decreases consistently in 332 the downstream direction. This may indicate that streamflow that gets warmer by the influx of relatively 333 warm groundwater through the streambed at the upstream of the study area, cools down slightly downstream 334 where stream water recharges groundwater.

\section{Figure 7 here.}

336 Figure 8 shows the mean temperature of the FO-DTS measurements taken on 26-October-2018 07:31-08:02 337 (Figure 8b) and 12:32-13:02 (Figure 8c), and the corresponding EC data inferred from the EMI survey 338 conducted in June 2018. It can be seen from Figure 8 that both EMI measured EC values and mean 339 temperature values from the FO-DTS measurements show an anomaly at around 550 meters, hence 340 consistently indicating upwelling groundwater at this location. The mean values of temperature 341 measurements taken on 26-October-2018 at 07:31-08:02, 10:51-11:21 and 12:32-13:02 successfully 342 indicated this warming anomaly at the top-of-the-streambed 550 meters upstream of the DTS unit. Note 343 that, the effect of solar radiation and shading increased gradually from the measurement period 07:31-08:02 344 (Figure 8b) towards 12:32-13:02 (Figure 8c) with the rising sun and resulted in high variations in the 345 temperature profile. Thus, solar radiation/shading effects should be avoided as much as possible to more 346 clearly identify groundwater signals in FO-DTS measurements.

\section{$347 \quad$ Figure 8 here.}


348 4.4. Nested Piezometers and Vertical Hydraulic Gradient Estimation

349 Figure 9 shows the vertical hydraulic gradient values (VHG) calculated by manual water level 350 measurements in piezometers and surface water at sites P1, P2 and P3 (see Figure 6 for locations). Site P1 351 shows consistent positive VHG values indicating strong downward flux that is increasing in magnitude from 352 June to November 2018. Site P2 is characterized by consistent upward gradient until 20-September-2018, 353 and later shows slight upward and downward gradient based on measurement combinations. Note that the 354 magnitude of the VHG is substantially lower compared to that at site P1. After 20-September-2018 the 355 response of the water level after purging at P2-D was very low which could be due to clogging of P2-D, 356 hence the results of VHG calculations involving P2-D were deemed as suspicious after this date (these 357 values are marked with circles in Figure 9b). At Site P3, VHG values calculated from individual and nested 358 piezometers were negative (-1.6\% to $-8 \%)$ indicating upward flux on 20-September-2018 and gradually 359 changed to slightly positive values after 24-October-2018 (for example $+0.2 \%$ to $+4.3 \%$ on 24 -October 360 2018) indicating no or minor downward flux after this date. Note that retrieval of correct head gradient data 361 is challenging for piezometers placed directly in the streambed (Anibas et al., 2011). This situation is more 362 notable in the presence of small hydraulic gradients, such as at sites P2 and P3, which increases the 363 sensitivity of the results to measurement errors.

Figure 9 here.

365 To observe the vertical hydraulic gradients at piezometer sites in a continuous manner, $\mathrm{HOBO}^{\circledR}$ pressure 366 transducers were installed at selected piezometers and surface water for the period 27-October to 7367 November-2018. A total of five pressure transducers were deployed: -near site P1 for atmospheric 368 correction, P2-S, P2 surface water, P3-S and P3-D. P2-D was neglected due to clogging. The VHG at site 369 P3 was calculated using piezometers P3-D and P3-S, and at site P2 using the surface water level data 370 together with piezometer P2-S (Figure 10). The VHG values at site P3 vary between $-0.2 \%$ (upward flux) 371 and $+1.6 \%$ (downward flux) with a more or less diurnal cycle, but the dominant character at this site is slight 372 downward flux for this period (Figure 10a). At site P2 minor upward flux was evident with VHG values 373 varying narrowly around $-0.5 \%$ with a diurnal signal (Figure $10 \mathrm{~b}$ ). Note that a diurnal signal in water level 374 measurements could be due to thermal artifacts in total pressure transducer readings (McLaughlin and 375 Cohen, 2011).

$376 \quad$ Figure 10 here.

377 The results of VHG have shown that while downstream of the study site (P1) was characterized by strong 378 downward gradient, the upstream part of the study area, namely P2 and P3 sites, was characterized by lower 
379 hydraulic gradient magnitudes changing from upwelling towards neutral to slightly downwelling starting

380 from late October, 2018 indicating seasonal variation in the direction of the gradient.

381 4.5. Vertical Flux Determination from Vertical Temperature Profiles

382 Vertical flux values were estimated from diurnal temperature variations at two different depths using the 383 amplitude method of Hatch et al., (2006). For example, Figure 11a-11d shows the air temperature during 384 the October-November 2018 measurement period, together with the raw temperature data series, amplitude 385 inference, and vertical flux estimation results at site P3. Diurnal variations in temperature measurements 386 lower than sensor precision were deemed unreliable. However, it is also important to note that low diurnal 387 variations can be the sign of strong upwelling. Table 2 summarizes the vertical flux estimates for three 388 measurement periods. Since Site P1 is characterized by strong downward VHG from piezometers, 389 temperature-based vertical flux was only estimated in June-July 2018 and indicates downward fluid flux 390 ranging between $\left(+2.2 \times 10^{-6}\right)-\left(+2.5 \times 10^{-6}\right) \mathrm{m} / \mathrm{s}$. While inferred flux behavior at $\mathrm{P} 2$ is in an upward direction 391 in September-October 2018 with values ranging between $\left(-5 \times 10^{-7}\right)-\left(-2 \times 10^{-6}\right) \mathrm{m} / \mathrm{s}$, this changes to a 392 downward direction with values ranging between $\left(+6 \times 10^{-7}\right)-\left(+1 \times 10^{-6}\right) \mathrm{m} / \mathrm{s}$ at a depth of $9.5 \mathrm{~cm}$ for the $28-$ 393 October-2018 to 02-November-2018 period (Table 2). Site P3 is characterized by consistent upward flux 394 direction in both September-October 2018 and October-November 2018 periods with vertical flux values 395 ranging between $\left(-1 \times 10^{-6}\right)-\left(-2 \times 10^{-5}\right) \mathrm{m} / \mathrm{s}$ and $\left(-2 \times 10^{-6}\right)-\left(-3 \times 10^{-6}\right) \mathrm{m} / \mathrm{s}$, respectively.

396 Note that these vertical flux values were estimated using the typical values of sediment and water thermal 397 properties suggested by the VFLUX program developers (see Section 3.4). The sensitivity toolbox of the 398 VFLUX program was used to investigate the possible errors in modeled vertical flux due to these assumed 399 thermal properties. The results of the one-at-a-time sensitivity analysis indicated that the modeled vertical 400 flux values are most sensitive to the sediment thermal conductivity parameter. For example, when the 401 sediment thermal conductivity value was decreased by $50 \%$, the modeled vertical flux range between ($\left.4024.2 \times 10^{-6}\right)-\left(-5.6 \times 10^{-6}\right) \mathrm{m} / \mathrm{s}$ (nearly two-fold increase in magnitude) and when the thermal conductivity value 403 was increased by $50 \%$, the modeled vertical flux range between $\left(+3.5 \times 10^{-7}\right)-\left(-3.2 \times 10^{-7}\right) \mathrm{m} / \mathrm{s}$ (nearly ten404 fold decrease in magnitude with change in flux direction for a certain period) at site P3 for the October405 November 2018 period. Note that the assumed sediment thermal conductivity value utilized in this study 406 represents an average value between the limits of measured streambed sediment thermal conductivity values 407 reported in the literature (Sebok and Muller, 2019).

408 Figure 11 here.

Table 2 here. 


\section{Discussion of the Results}

The objective of this study was to quantify the spatio-temporal distribution of the groundwater-stream 412 exchange fluxes along the Çakıt stream in a hierarchical manner. The hierarchical approach started at the 413 basin scale and focused on stream reach scale in a step-wise manner using geology, geomorphology, major ion analyses, electromagnetic induction surveys, fiber-optic distributed temperature sensing technology, nested piezometers and streambed vertical temperature profiles.

The study has shown that EMI survey is an efficient and effective method to identify zones within streambed sediments which may indicate localized upwelling locations. The EMI survey was conducted using the GF Instruments CMD-1 probe, which is only capable of taking measurements at single depth. However, performing EMI surveys at multiple depths would provide a stronger conceptualization of the streambed sediments (Binley et al., 2013; Rejiba et al., 2018) and possibly underlying hydrogeological architecture (Rosenberry et al., 2016). Although EMI surveys were performed in September and October, 2018, the results were not reliable due to the distorted coordinates of the data. Under cloudy and rainy weather conditions, GPS devices (even with high sensitivity) can fail to give exact position in highly vegetated areas, and therefore weather conditions need to be considered for the techniques that requires highly sensitive coordinate data. In this study an EMI survey was conducted along a 2-km reach of the Çakıt stream, which is considerably longer compared to previous studies focusing on EMI surveys to locate exchange flux location; for example, Binley et al. (2013) and Gaona et al. (2019) utilized EMI survey along a $200 \mathrm{~m}$ and a $45 \mathrm{~m}$ reach, respectively. Although dense vegetation along the stream and changing river bed conditions presented difficulties in EMI surveys, the results provided spatial patterns of stream bed conductivity that in turn helped to successfully infer the local subsurface flow paths as highlighted by Robinson et al. (2008). Interpretation of the EMI measurements relies on a significant contrast in upwelling pore water electrical conductivity and more diffusive groundwater upwelling will not be detected.

The application of FO-DTS provided promising results under certain conditions including cold weather (marked temperature difference between stream water and groundwater); minimal shading effect (early morning and cloudy conditions) and low streamflow conditions (less turbulent mixing along the streambed) (Matheswaran et al., 2014). An important finding of this study is that, under favorable conditions listed above, the FO-DTS temperature anomaly location coincided with the location of the EMI EC anomaly. This result indicates that these two independent methods supported each other and hence they may complement each other at different scales. While EMI survey could be conducted readily over long distances as long as the stream conditions permit, FO-DTS measurements could be utilized at focused reaches to support EMI survey results. Observation of transient conditions such as seasonal variation and flood events would also provide useful information on temporal variability in the exchange fluxes (Gaona et al., 2019). 
443 The vertical flux values estimated from iButton thermochrone temperature sensors and vertical hydraulic 444 gradient values obtained from nested piezometers provided quantitative insight for the stream reach at the 445 point-scale (Constantz, 2008; Kalbus et al., 2006). Both vertical temperature profiles and vertical hydraulic 446 gradients agreed with the EMI and DTS surveys and indicated upward vertical water flow direction in 447 upstream locations P2 and P3 during 18-September-2018 to 3-October-2018 period. However, these point448 based methods did not always provide consistent results with each other and with EMI and DTS 449 measurements during the 26-October-2018 to 7-November-2018 measurement period. This result could be 450 explained by the fact that point-scale methods, being highly sensitive to local conditions, may not be 451 indicative of the heterogeneity of the exchange processes at the broader scale that could be revealed by the 452 EMI and FO-DTS data that are integrated over a range of scales. This heterogeneity of exchange processes 453 in time and space highlights the importance incorporating multi-scale observations in a hierarchical manner 454 in characterization of the groundwater-surface water exchange processes. Overall, a combination of 455 different methods helps to overcome the limitations of each single method and increases confidence in the 456 obtained results.

457 In summary, incorporation of the geophysical methods, namely EMI and DTS, enabled identification of 458 potential groundwater upwelling locations along the streambed, which would not have been possible with 459 point-based methods alone due to the large extent of the study area. The hierarchical approach presented in 460 this study could easily be transferred to other locations provided that the necessary instruments are available 461 for measurements at various scales. Our recommendations for future applications include performing EMI 462 surveys sensitized to multiple depths to infer both hydrogeological structure and streambed heterogeneity, 463 and utilizing solar panels for energy source to enable continuous monitoring of the temperature profile along 464 the reach with the FO-DTS instrument. Moreover, increasing the point-based data collection locations could 465 provide further insight into local heterogeneity, however this option would come with a cost in terms of 466 time and budget (Conant, 2004) which were not available for this study and hence recommended for future 467 studies.

\section{6. Conclusion}

469 In summary, the results indicate that the studied stream reach show different characteristics at downstream 470 and upstream locations. While downwelling is the dominant behavior for the downstream of the study reach, 471 upwelling is evident at some locations of the upstream of the study reach during the early part of the study 472 period.

473 The study has shown that EMI surveys which can be conducted at long stream reaches in a relatively short 474 time period could be utilized as a valuable reconnaissance method to locate preferential groundwater-stream 
475 exchange locations. Moreover, FO-DTS can be further utilized as a complimentary method over shorter 476 distances to provide continuous observations in time and space in support of EMI surveys. In this study, a 477 high EC anomaly location obtained from the EMI survey coincided with the location of a temperature 478 anomaly observed by FO-DTS. The joint use of these methods is a significant highlight of the study. Point479 based methods of vertical hydraulic gradient estimation from hydraulic head measurements and vertical flux 480 estimation from vertical temperature transects can provide quantitative results to support EMI and FO-DTS 481 measurements once anomaly locations are determined with EMI and FO-DTS surveys. Our results indicate 482 that point-based methods may not always agree with the EMI and DTS surveys, due to mismatch between 483 the representative scales and highly heterogeneous nature of the streambed exchange processes. However, 484 the use of different set of techniques that are sensitive to different space and time scales in a hierarchical 485 manner helps to overcome the limitations of each single method and increases confidence in the obtained 486 results. 
502

503

504

505

506

507

508

509

510

511

512

513

514

515

516

517

518

519

520

521

522

523

524

525

526

527

528

\section{References}

Anderson, M. P. (2005). Heat as a ground water tracer. Ground Water, 43, no. 6: 951-968, doi.org/10.1111/j.1745-6584.2005.00052.x.

Anibas C, Verbeiren B, Buis K, Chormański J, De Doncker L, Okruszko T, Meire P, Batelaan O (2012) A hierarchical approach on groundwater-surface water interaction in wetlands along the upper Biebrza River, Poland. Hydrol. Earth. Syst. Sci., 16:2329-2346. doi:10.5194/hess-16-2329-2012

Baxter, C., Hauer, F. R., and Woessner, W. W. (2003). Measuring groundwater-stream water exchange: new techniques for installing minipiezometers and estimating hydraulic conductivity. Transactions of the American Fisheries Society, 493-502.

Binley, A., Hubbard, S. S., Huisman, J. A., Revil, A., Robinson, D. A., Singha, K., and Slater, L. D. (2015). The emergence of hydrogeophysics for improved understanding of subsurface processes over multiple scales. Water Resour. Res., 51 , 3837-3866, doi:10.1002/2015WR017016.

Binley, A., S. Ullah, A. L. Heathwaite, C. Heppell, P. Byrne, K. Lansdown, M. Trimmer, and H. Zhang (2013), Revealing the spatial variability of water fluxes at the groundwater-surface water interface. Water Resour. Res., 49, 3978-3992, doi:10.1002/wrcr.20214.

Bredehoeft, J. D., and Papaopulos, I. S. (1965). Rates of vertical groundwater movement estimated from the Earth's thermal profile. Water Resour. Res., 1, 325-328, https://doi.org/10.1029/WR001i002p00325.

Brodie, R., Sundaram, B., Tottenham, R., Hostetler, S., and Ransley, T. (2007). An Overview of Tools for Assessing Groundwater-Surface Water Connectivity. Canberra: Bureau of Rural Sciences.

Conant, J. B. (2004). Delineating and quantifying ground water discharge zones using streambed temperatures. Ground Water, 243-257.

Constantz, J. (2008). Heat as a tracer to determine streambed water exchanges. Water Resour. Res., 44, W00D10, doi:10.1029/2008WR006996.

Crook, N., Binley, A., Knight, R., Robinson, D. A., Zarnetske, J., and Haggerty, R. (2008). Electrical resistivity imaging of the architecture of substream sediments. Water Resour. Res., 44, W00D13, doi:10.1029/2008WR006968. 
529 Frederiksen R.R., Christensen S., and Rasmussen K.R. (2018). Estimating groundwater discharge to a 530 531 532 533 534 535 536 537 538 539 540 541 542 543 544 545 546 547 548 549 550 551 552 553 554 555 556 lowland alluvial stream using methods at point-, reach-, and catchment-scale. Journal of Hydrology, 564: 836-845.

Gaona, J., Meinikmann, K., and Lewandowski, J. (2019). Identification of groundwater exfiltration, interflow discharge, and hyporheic exchange flows by fibre optic distributed temperature sensing supported by electromagnetic induction geophysics. Hydrological Processes, 33:1390-1402. https://doi.org/10.1002/hyp.13408.

González-Pinzón R, Ward AS, Hatch CE, Wlostowski AN, Singha K, Gooseff MN, Haggerty R, Harvey JW, Cirpka OA, and Brock JT. 2015. A field comparison of multiple techniques to quantify groundwater-surface-water interactions. Freshwater Science 34: 139-160.

Gordon, R. P., Lautz, L. K., and Daniluk, T. L. (2013). Spatial patterns of hyporheic exchange and biogeochemical cycling around cross-vane restoration structures : Implications for stream restoration design. Water Resour. Res., 49, 2040-2055, doi:10.1002/wrcr.20185.

Gordon, R. P., Lautz, L. K., Briggs, M. A., and McKenzie, J. M. (2012). Automated calculation of vertical pore-water flux from field temperature time series using the VFLUX method and computer program. Journal of Hydrology, 142-158.

Hatch, C. E., Fisher, A. T., Revenaugh, J. S., Constantz, J., and Ruehl, C. (2006). Quantifying surface water-groundwater interactions using time series analysis of streambed thermal records: method development. Water Resour. Res., 42, W10410, doi:10.1029/2005WR004787.

Hausner, M. B., Suarez, F., Glander, K. E., and Van de Giesen, N. (2011). Calibrating Single-Ended Fiber-Optic Raman Spectra Distributed Temperature Sensing Data. Sensors, 11, 10859-10879; doi:10.3390/s111110859.

Kalbus, E., Reinstorf, F., and Schirmer, M. (2006). Measuring methods forgroundwater, surface water and their interactions: a review. Hydrol. Earth Syst. Sci., 10, 873-887, doi.org/10.5194/hess-10-8732006.

Keery, J., Binley, A., Crook, N., and Smith, J. W. (2007). Temporal and Spatial Variability of groundwater - surface water fluxes: Development and application of an analytical method using temperature time series. Journal of Hydrology, 336, 1-16, doi:10.1016/j.jhydrol.2006.12.003. 
557 Kennedy, C. D., Genereux, D. P., Corbett, R., and Mitasova, H. (2009). Spatial and temporal dynamics of coupled groundwater and nitrogen fluxes through a streambed in an agricultural watershed. Water Resources Res, 45, W09401, doi:10.1029/2008WR007397.

Klos, P.Z., Rosenberry, D.O., Nelson, G.R. (2015) Influence of hyporheic exchange, substrate distribution, and other physically linked hydrogeomorphic characteristics on abundance of freshwater mussels. Ecohydrology 8: 1284-1291.

Krause, S., Blume, T., and Cassidy, N. J. (2012). Investigating patterns and controls of groundwater upwelling in a lowland river by combining Fibre-optic Distributed Temperature Sensing with observations of vertical hydraulic gradients. Hydrol. Earth Syst. Sci., 16, 1775-1792, doi:10.5194/hess-16-1775-2012.

Lapham, W. W. (1989). Use of Temperature Profiles Beneath Streams to Determine Rates of Vertical Ground-Water Flow and Vertical Hydraulic Conductivity. Denver: U.S. Geological Survey Water-Supply Paper 2337.

Lowry, C.S., Walker, J.F., Hunt, R.J., and Anderson, M.P. (2007). Identifying spatial variability of groundwater discharge in a wetland stream using a distributed temperature sensor: Water Resour. Research, v. 43, no. 10, p. W10408.Matheswaran, K., Blemmer, M., Rosbjerg, D., and Boegh, E. (2014). Seasonal variations in groundwater upwelling zones in a Danish lowland stream analyzed using Distributed Temperature Sensing (DTS). Hydrol. Process., 28, 1422-1435, DOI: 10.1002/hyp.9690.

McLaughlin, D. L. and M. J. Cohen, (2011), Thermal artifacts in measurements of fine-scale water level variation, Water Resour. Res., W09601, doi:10.1029/2010WR010288.

McNeill, J. D. (1980). Electromagnetic terrain conductivity measurements at low induction numbers. GEONICS Tech. Note TN6., Mississauga, Ont., Canada, Geonics.

Rejiba, F., Schamper, C., Chevalier, A., Deleplancque, B., Hovhanissian, G., Thiesson, J., and Weill, P. (2018). Multiconfiguration electromagnetic induction survey for paleochannel internal structure imaging: a case study in the alluvial plain of the River Seine, France. Hydrol. Earth Syst. Sci., 22, 159-170, 2018, doi.org/10.5194/hess-22-159-2018.

Robinson, D. A., A. Binley, N. Crook, F. D. Day-Lewis, T. P. A. Ferré, V. J. S. Grauch, R. Knight, M. Knoll, V. Lakshmi, R. Miller, J. Nyquist, L. Pellerin, K. Singha, and L. Slater (2008). Advancing process-based watershed hydrological research using near-surface geophysics: a vision for, and review of, electrical and magnetic geophysical methods. Hydrol. Process., 22, 3604-3635, 2008, DOI: 10.1002/hyp.6963. 
589 Rosenberry, D.O., Briggs, M.A., Delin, G. and Hare, D.K. (2016). Combined use of thermal methods and

590

591

592

593

594

595

596

597

598

599

600

601

602

603

604

605

606

607

608

609

610

611

612

613

614

615

616

617

618 seepage meters to efficiently locate, quantify, and monitor focused groundwater discharge to a sand-bed stream. Water Resour. Res., 52: 4486-4503.

Rosenberry D.O., and LaBaugh J.W. (2008). Field techniques for estimating water fluxes between surface water and ground water. U.S. Geological Survey Techniques and Methods 4-D2; 128.

Sebok, E. and S. Muller (2019), The effect of sediment thermal conductivity on vertical groundwater flux estimates, Hydrol. Earth Syst. Sci., 23, 3305-3317.

Selker, J. S., L. Thevenaz, H. Huwald, A. Mallet, W. Luxemburg, N. van de Giesen, M. Stejskal, J. Zeman, M. Westhoff, and M. B. Parlange (2006a). Distributed fiber-optic temperature sensing for hydrologic systems. Water Resour. Res., 42, W12202, doi:10.1029/2006WR005326.

Selker, J., Van de Giesen, N. C., Westhoff, M., Luxemburg, W. M., and Parlange, M. B. (2006b). Fiber optics opens window on stream dynamics. Geophysical Research Letters, 33, L24401, doi:10.1029/2006GL027979.

Sophocleous, M. (2002). Interactions between groundwater and surface water: the state of the science. Hydrogeology Journal, 52-67, doi.org/10.1007/s10040-001-0170-8.

Stallman, R. W. (1963). Computation of ground-water velocity from temperature data. Geological Survey Water-Supply Paper, 1544-H, 36-46.

State Hydraulic Works (2014). Seyhan Basin Master Plan Report. State Hydraulic Works, Ankara, Turkey.

Suzuki, S. (1960). Percolation measurements based on heat flow through soil with special reference to paddy fields. Journal of Geophysical Research, 65-69.

Tristram, D.A., Krause, S., Levy, A., Robinson, Z.P., Waller, R.I., and Weatherill, J.J. (2015). Identifying spatial and temporal dynamics of proglacial groundwater-surface-water exchange using combined temperature-tracing methods. Freshwater Science, v. 34, no. 1, p. 99-110.

Van de Giesen, N., Steele-Dunne, S., Jansen, J., Hoes, O., Hausner, M. B., Tyler, S., and Selker, J. (2012). Double-Ended Calibration of Fiber-Optic Raman Spectra Distributed Temperature Sensing Data. Sensors, 12, 5471-5485; doi:10.3390/s120505471.

Varli, D., \& Yilmaz, K. K. (2018). A Multi-Scale Approach for Improved Characterization of Surface Water-Groundwater Interactions: Integrating Thermal Remote Sensing and in-Stream Measurements. Water, 10, 854; doi:10.3390/w10070854. 
619 Winter, T. C., Harvey, J. W., Franke, O. L., \& Alley, W. M. (1998). Ground Water and Surface Water A $620 \quad$ Single Resource. U. S. Geological Survey, Circular 1139.

621

622 Data Availability Statement

623 The data that support the findings of this study are available from the corresponding author upon reasonable 624 request.

625

626

627

628

629

630

631

632

633

634

635

636

637

638

639

640

641

642 


\section{Figure Captions:}

644 Figure 1 (a) Regional view of the study basin and location of the reach-scale study area indicated by the red

645 line, (b) Geological formations within the basin (State Hydraulic Works, 2014) and in-stream electrical 646 conductivity $(\mathrm{EC} ; \mu \mathrm{S} / \mathrm{cm})$ values at the sampling locations (measured on June, 2016)

647 Figure 2 Piezometer installation units; (a) Metal pointed inner driver rod, (b) Outer metal tube that prevents

648 collapse of the borehole during installation of the piezometer, and (c) driving in installation units into 649 streambed

650 Figure 3 (a) iButton configurations at each location, (b) photo showing the configuration at location P1 in 651 the June 2018 field trip.

652 Figure 4 Piper diagram showing ionic composition of samples collected on June, 2016.

653 Figure $5 \mathrm{EC}(\mu \mathrm{S} / \mathrm{cm})$ results inferred from EMI Survey performed on 31-January-2018. Note that the entire 654 reach shown in this figure is equivalent to the reach indicated in red in Figure 1a, and the stream reach 655 within the rectangle in this figure is the same as the study reach shown in Figure 6.

656 Figure 6 (a)Map showing the locations of nested piezometers, vertical temperature profiles (iButtons) and 657 DTS transect along with EMI Survey conducted on 27-June-2018 (note that green triangle marker represents 658 an irrigation water diversion barrier). (b) EC data inferred from the EMI survey along the study reach 659 (distance is measured from the downstream end of the transect).

660 Figure 7 FO-DTS results of two measurement periods: (a,b,c) 18 September, 2018 13:28 -13:53 for which 661 results are effected by shading, (d,e,f) 26 October, 2018 07:31-08:02 with clear temperature anomaly. (a,d) 662 10-minute air temperature records of the day of measurement from nearest meteorological station; box 663 indicates FO-DTS measurement interval, $(\mathrm{b}, \mathrm{e})$ FO-DTS temperature measurement values along the transect 664 (y-axis) in time (x-axis), (c,f) Mean temperature values for each measurement point in time. This graph also 665 shows a moving average of the mean temperature to be able to focus on persistent variations along the 666 transect. Note that the data were deleted from both graphs for sections that FO cable remained out of water. 667 These sections include a barrier location at around 325-328 meters, and another location at 195 meters for 668 the September measurement (b). Figure 8 (a) air temperature on 26-October-2018, (b) EC data inferred from EMI Survey (June, 2018) overlain by mean top-of-the-streambed temperature values measured by the DTS unit on 26-October- 2018 at time 07:31-08:02, and (c) same as (b) but at time 12:32-13:02. Note that green dashed circles in (c)

672 indicate the effect of sunlight and shading which are not present in (b).

673 Figure 9 Vertical Hydraulic Gradient (VHG) (\%) values calculated using manual water level 674 measurements at (a) site P1, (b) site P2, and (c) site P3 during June-November 2018 period. Note that the 675 VHG values become more positive as going from June, 2018 through November, 2018. Circled VHG 676 values in (b) were deemed suspicious due to clogging of piezometer P2D.

677 Figure 10 Water level measurements using pressure transducers (HOBO) and vertical hydraulic gradient 678 values at (a) Site P3 and (b) Site P2 during 27-October-2018 to 7-November-2018 period.

679 Figure 11 (a) Air temperature, (b) raw temperature data series, (c)amplitude variation and (d) estimated 680 vertical flux values at site P3 for the 26-October-2018 to 7-November-2018 measurement period. 
Table 1. FO-DTS measurement time periods and statistics together with air temperature and stream discharge at nearest meteorological station and Çakıt stream gauging station, respectively.

\begin{tabular}{|c|c|c|c|c|c|c|c|c|}
\hline \multicolumn{2}{|c|}{ FO-DTS Measurements } & \multicolumn{3}{|c|}{$\begin{array}{c}\text { FO-DTS Stream } \\
\text { Measurement }\left({ }^{\circ} \mathrm{C}\right)\end{array}$} & \multicolumn{3}{|c|}{ Air Temperature $\left({ }^{\circ} \mathrm{C}\right)$} & \multirow{2}{*}{$\begin{array}{c}\text { Stream } \\
\text { Discharge } \\
\left(\mathrm{m}^{3} / \mathrm{s}\right)\end{array}$} \\
\hline Date & Time & Min & Mean & Max & Min & Mean & Max & \\
\hline 27-June-2018 & $17: 51-18: 14$ & 19.51 & 19.96 & 20.45 & 29.82 & 29.93 & 30.12 & 0.754 \\
\hline \multirow{2}{*}{ 28-Jun- 2018} & $11: 18-12: 12$ & 16.51 & 17.69 & 18.80 & 28.52 & 29.25 & 29.72 & \multirow{2}{*}{0.711} \\
\hline & $17: 49-18: 31$ & 19.22 & 19.86 & 20.45 & 25.22 & 25.86 & 26.51 & \\
\hline \multirow{3}{*}{ 18-Sep-2018 } & $10: 49-11: 15$ & 14.37 & 15.10 & 16.03 & 21.91 & 22.09 & 22.18 & \multirow{3}{*}{0.817} \\
\hline & $13: 28-13: 53$ & 16.90 & 17.56 & 18.22 & 24.48 & 24.60 & 24.83 & \\
\hline & $17: 33-17: 48$ & 15.76 & 16.53 & 17.24 & 23.58 & 23.88 & 24.14 & \\
\hline \multirow{4}{*}{ 25-Oct- 2018} & 07:41-08:11 & 11.17 & 11.66 & 12.17 & 10.58 & 11.59 & 12.42 & \multirow{4}{*}{0.672} \\
\hline & $10: 54-11: 34$ & 11.34 & 11.87 & 12.39 & 10.51 & 10.59 & 10.76 & \\
\hline & $12: 15-12: 45$ & 11.90 & 12.44 & 12.97 & 11.49 & 11.55 & 11.68 & \\
\hline & $14: 48-15: 18$ & 12.19 & 12.68 & 13.22 & 7.81 & 9.19 & 11.43 & \\
\hline \multirow{3}{*}{ 26-Oct-2018 } & 07:31-08:02 & 8.88 & 9.53 & 10.09 & 2.62 & 3.24 & 3.58 & \multirow{3}{*}{0.678} \\
\hline & $10: 51-11: 21$ & 9.18 & 9.69 & 10.21 & 2.15 & 2.50 & 2.83 & \\
\hline & $12: 32-13: 02$ & 9.73 & 10.43 & 11.11 & 4.59 & 5.22 & 5.51 & \\
\hline
\end{tabular}


Table 2. Vertical flux estimates using VFLUX

\begin{tabular}{|c|c|c|c|c|}
\hline Time Period & Site & $\begin{array}{c}\text { Depth below } \\
\text { top of } \\
\text { streambed }(\mathrm{cm})\end{array}$ & Vertical flux (m/s) & $\begin{array}{c}\text { Flow } \\
\text { direction }\end{array}$ \\
\hline $\begin{array}{c}28.06 .2018 \text { - } \\
02.07 .2018\end{array}$ & $\mathrm{P} 1$ & 9.5 & $\left(+2.2 \times 10^{-6}\right)-\left(+2.5 \times 10^{-6}\right)$ & Downward \\
\hline \multirow{2}{*}{$\begin{array}{c}18.09 .2018- \\
03.10 .2018\end{array}$} & $\mathrm{P} 2$ & 9.5 & $\left(-5 \times 10^{-7}\right)-\left(-2 \times 10^{-6}\right)$ & Upward \\
\hline & P3 & 5.5 & $\left(-1 \times 10^{-6}\right)-\left(-1 \times 10^{-5}\right)$ & Upward \\
\hline \multirow{2}{*}{$\begin{array}{c}26.10 .2018- \\
07.11 .2018\end{array}$} & $\mathrm{P} 2$ & 9.5 & $\left(+6 \times 10^{-7}\right)-\left(+1 \times 10^{-6}\right)$ & Downward \\
\hline & P3 & 9.5 & $\left(-2 \times 10^{-6}\right)-\left(-3 \times 10^{-6}\right)$ & Upward \\
\hline
\end{tabular}



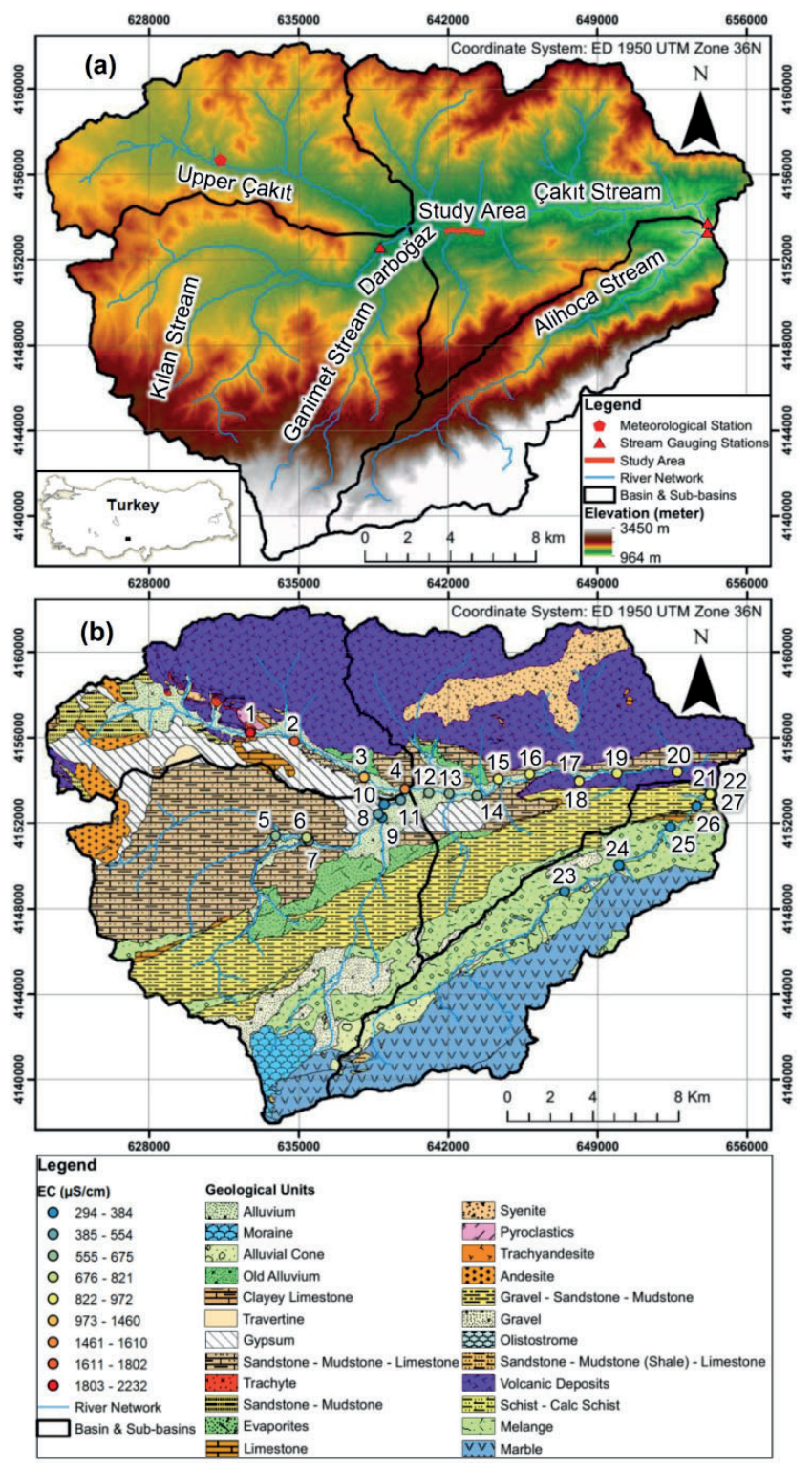

Figure 1 (a) Regional view of the study basin and location of the reach-scale study area indicated by the red line, (b) Geological formations within the basin (State Hydraulic Works, 2014) and in-stream electrical conductivity $(\mathrm{EC} ; \mu \mathrm{S} / \mathrm{cm})$ values at the sampling locations (measured on June, 2016) 

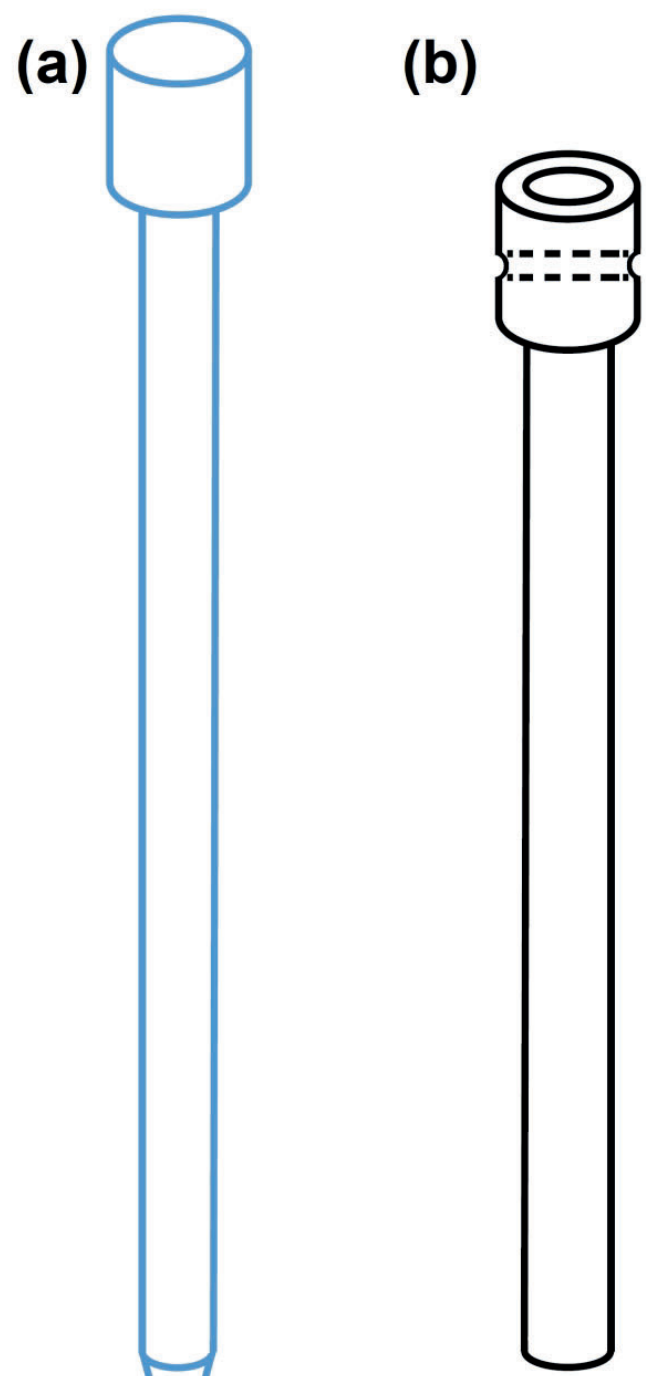

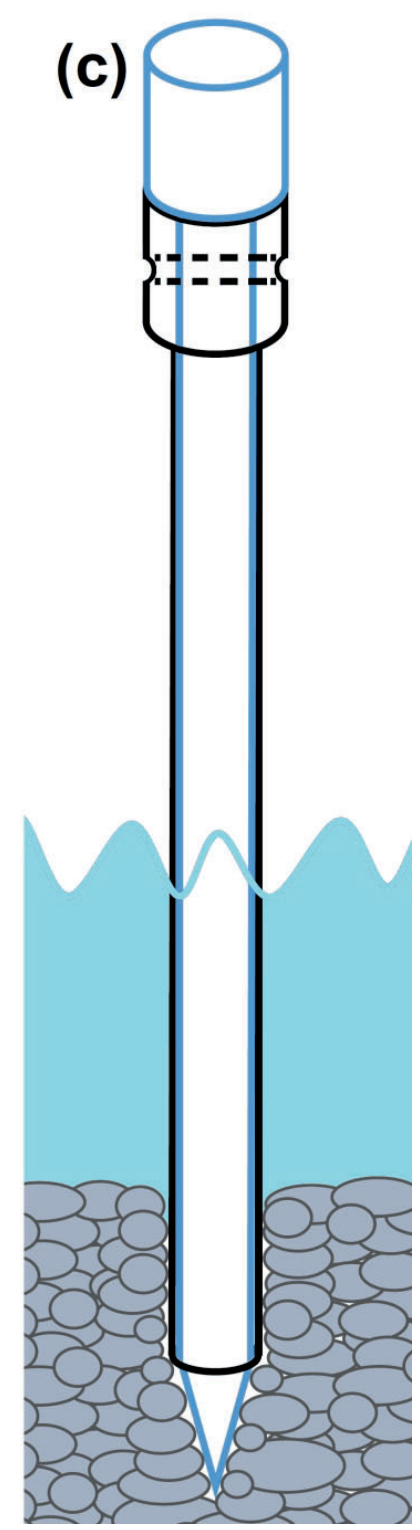

Figure 2 Piezometer installation units; (a) Metal pointed inner driver rod, (b) Outer metal tube that prevents collapse of the borehole during installation of the piezometer, and (c) driving in installation units into the streambed 

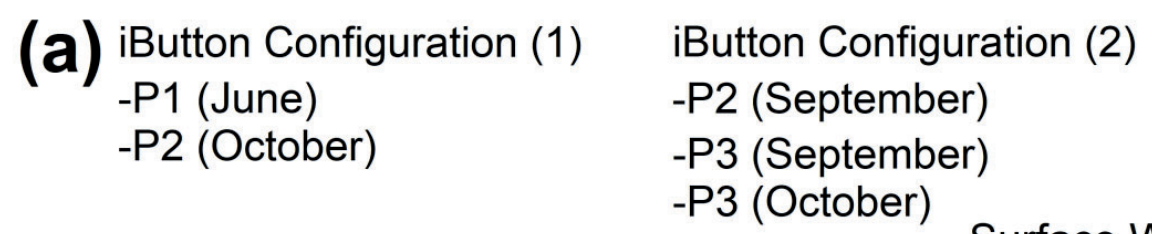

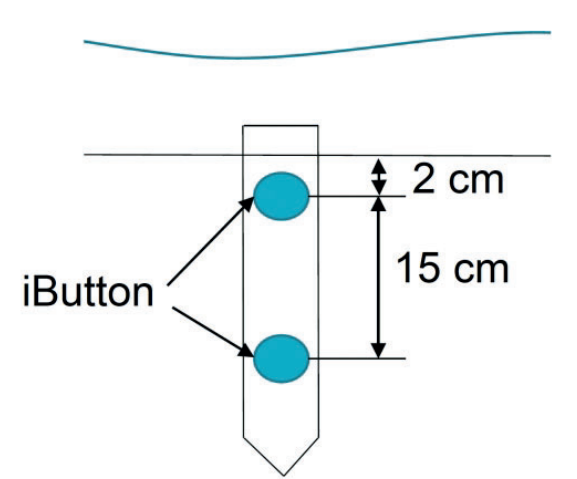

(1)

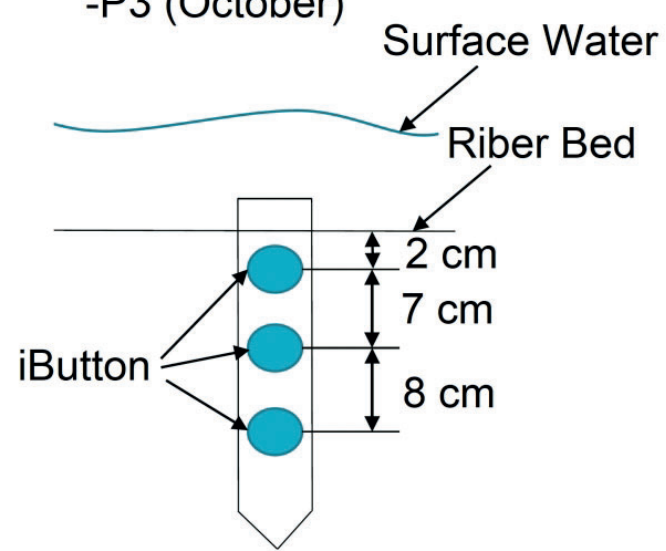

(2)

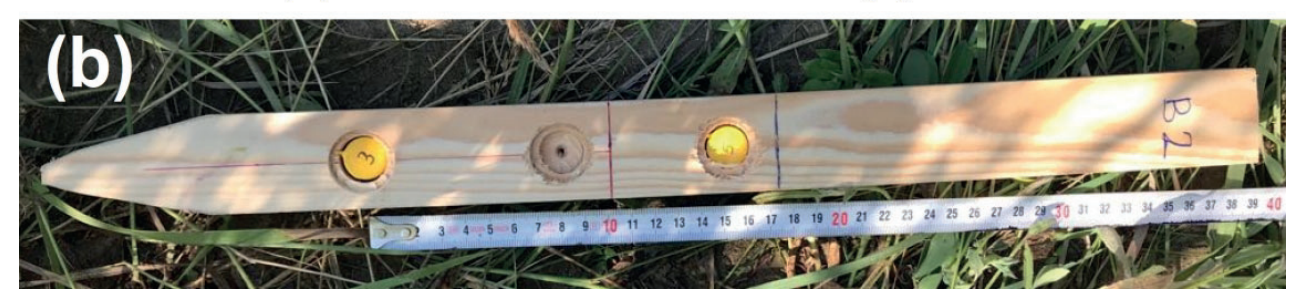

Figure 3 (a) iButton configurations at each location, (b) photo showing the configuration at location P1 in the June 2018 field trip. 


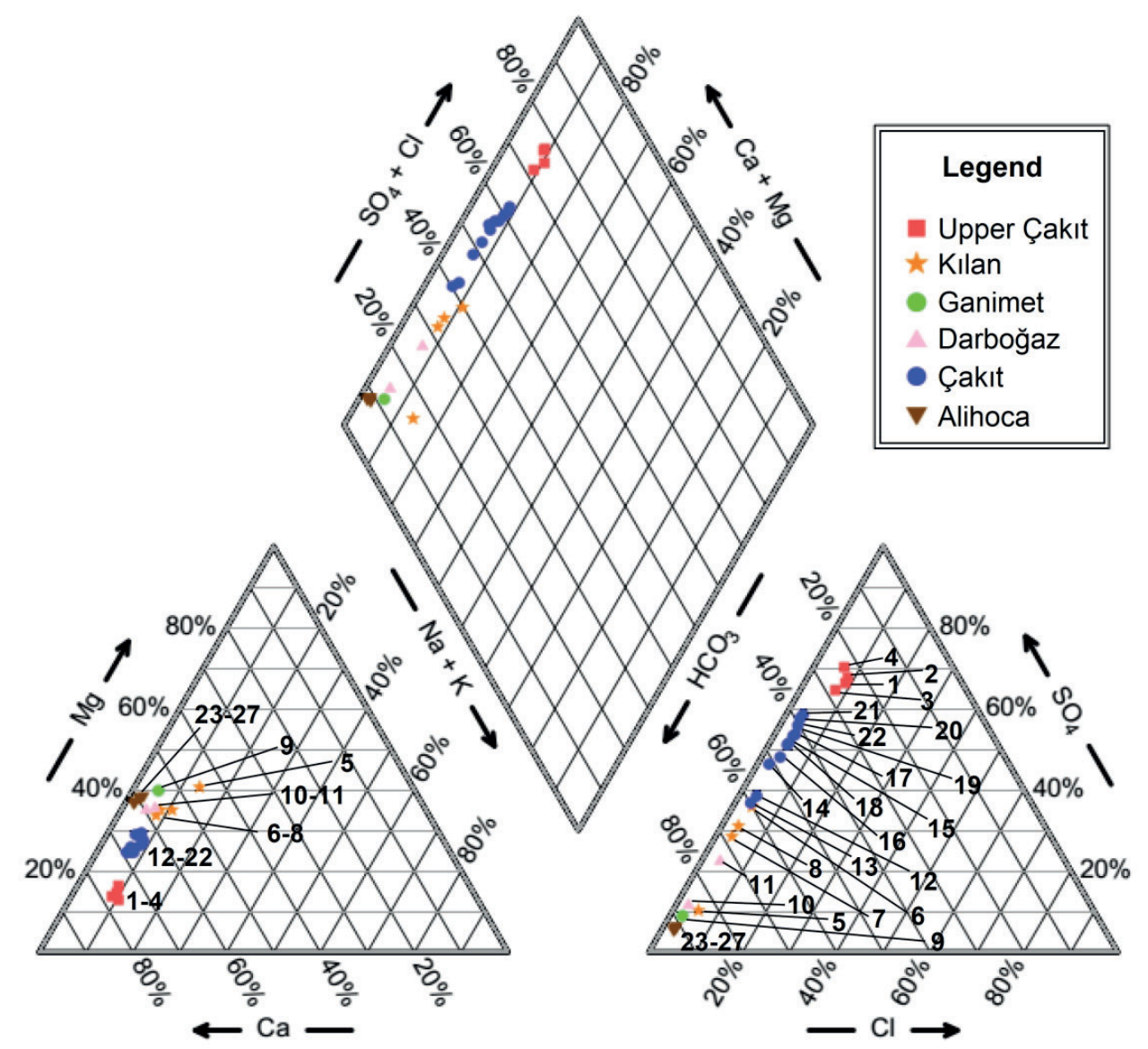

Figure 4 Piper diagram showing ionic composition of samples collected on June, 2016. 


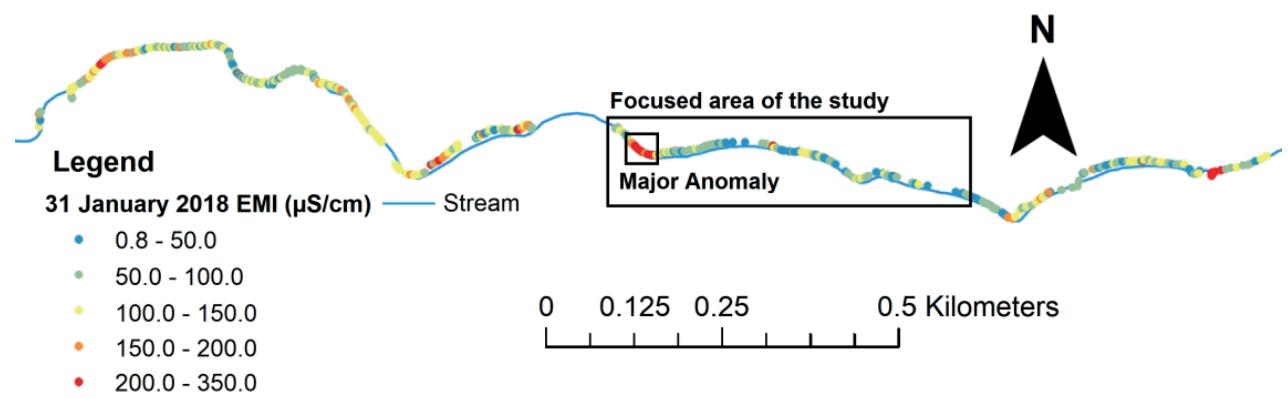

Figure $5 \mathrm{EC}(\mu \mathrm{S} / \mathrm{cm})$ results inferred from EMI Survey performed on 31-January-2018. Note that the entire reach shown in this figure is equivalent to the reach indicated in red in Figure $1 a$, and the stream reach within the rectangle in this figure is the same as the study reach shown in Figure 6. 


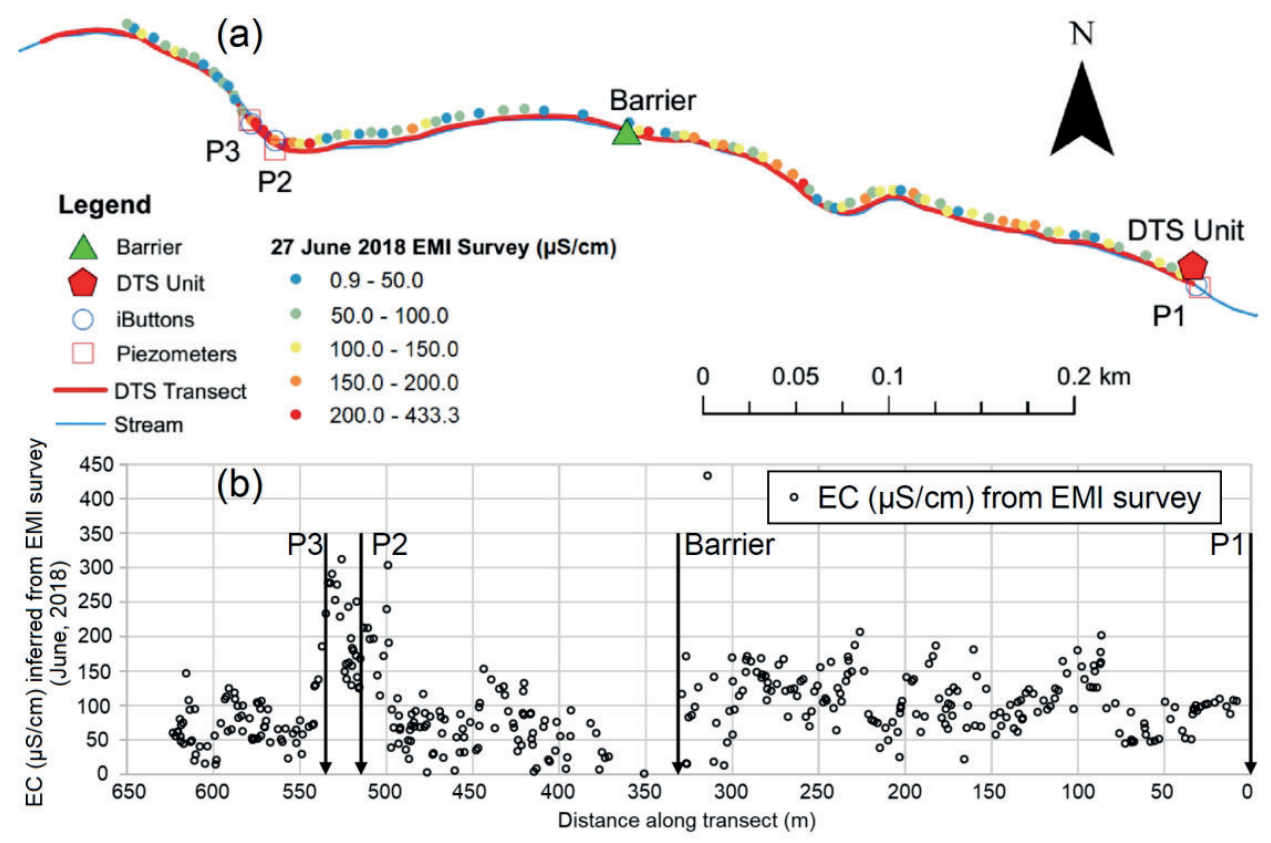

Figure 6 (a)Map showing the locations of nested piezometers, vertical temperature profiles (iButtons) and DTS transect along with EMI Survey conducted on 27-June-2018 (note that green triangle marker represents an irrigation water diversion barrier). (b) EC data inferred from the EMI survey along the study reach (distance is measured from the downstream end of the transect). 


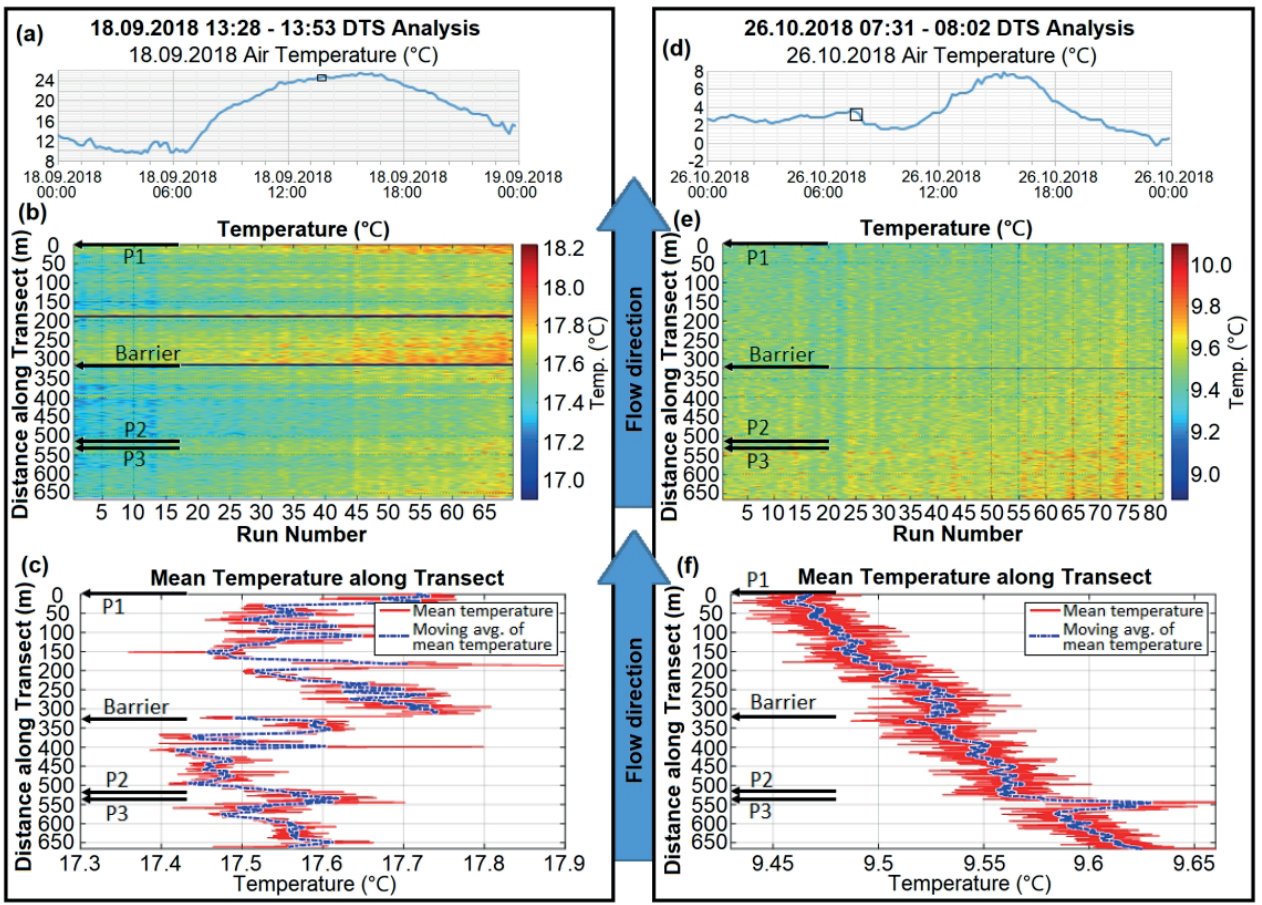

Figure 7 FO-DTS results of two measurement periods: $(a, b, c) 18$ September, 2018 13:28 -13:53 for which results are effected by shading, (d,e,f) 26 October, 2018 07:31-08:02 with clear temperature anomaly. $(a, d) 10$-minute air temperature records of the day of measurement from nearest meteorological station; box indicates FO-DTS measurement interval, $(b, e)$ FO-DTS temperature measurement values along the transect (y-axis) in time ( $x$-axis), $(c, f)$ Mean temperature values for each measurement point in time. This graph also shows a moving average of the mean temperature to be able to focus on persistent variations along the transect. Note that the data were deleted from both graphs for sections that FO cable remained out of water. These sections include a barrier location at around 325-328 meters, and another location at 195 meters for the September measurement (b). 
26.10.2018 Air Temperature $\left({ }^{\circ} \mathrm{C}\right)$

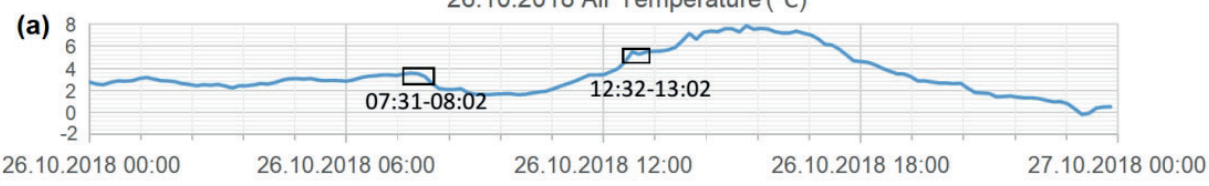

Mean Temperature $\left({ }^{\circ} \mathrm{C}\right)$ of Measurements 07:31-08:02 Mean Temperature $\left({ }^{\circ} \mathrm{C}\right)$ of Measurements 12:32-13:02

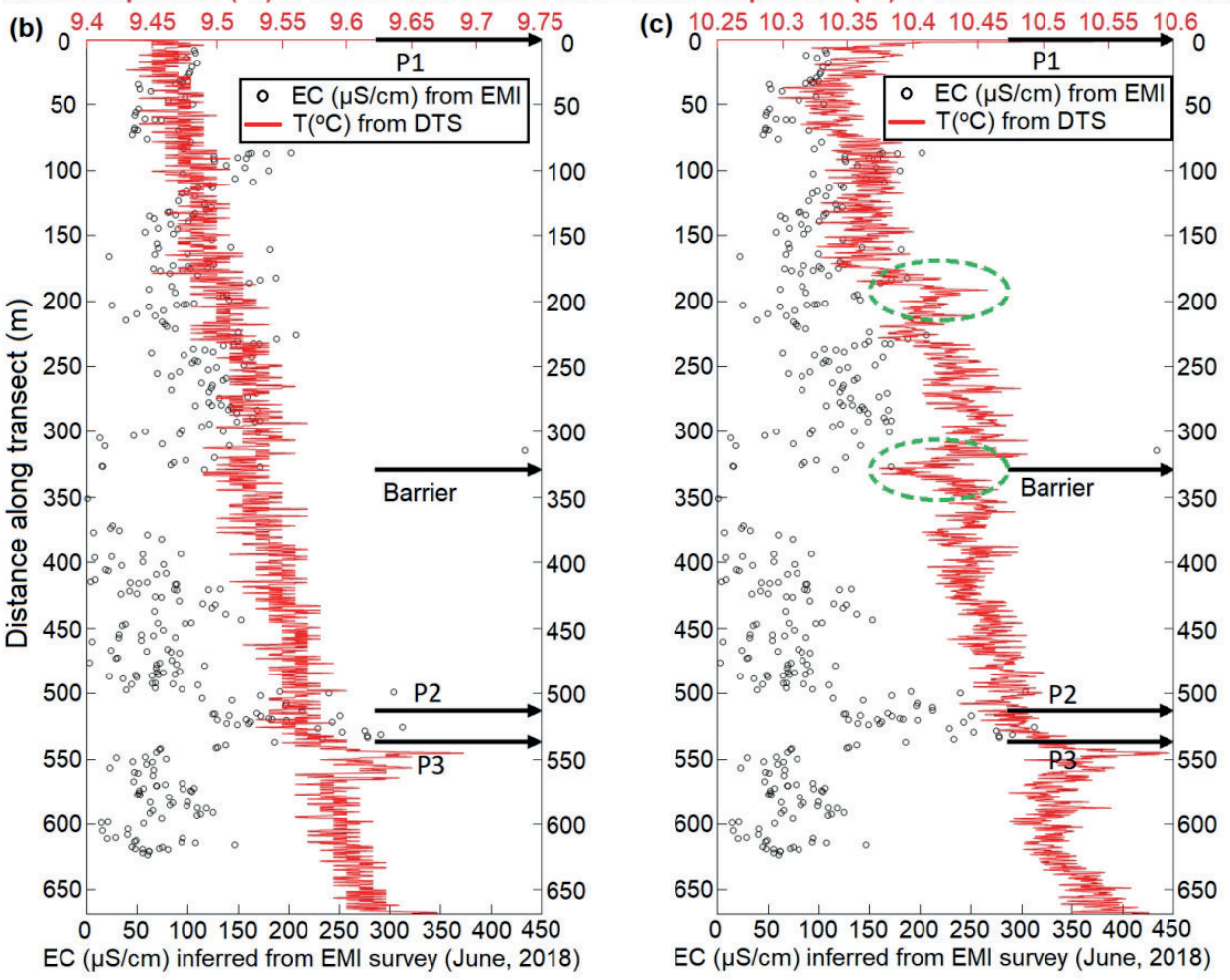

Figure 8 (a) air temperature on 26-October-2018, (b) EC data inferred from EMI Survey (June, 2018) overlain by mean top-of-the-streambed temperature values measured by the DTS unit on 26-October- 2018 at time 07:31-08:02, and (c) same as (b) but at time 12:32-13:02. Note that green dashed circles in (c) indicate the effect of sunlight and shading which are not present in (b). 


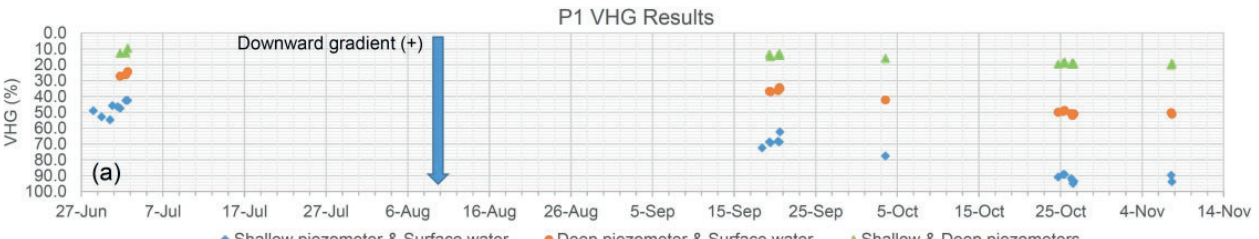

P2 VHG Results

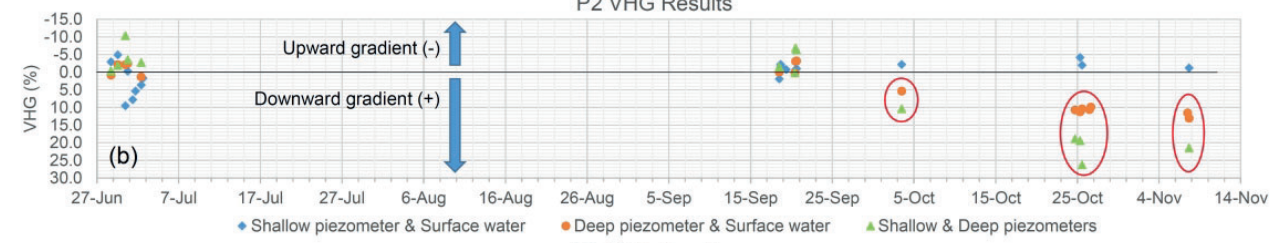
P3 VHG Results

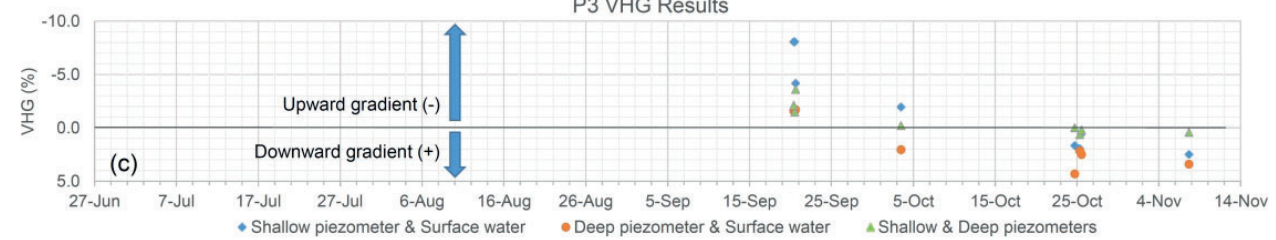

Figure 9 Vertical Hydraulic Gradient (VHG) (\%) values calculated using manual water level measurements at (a) site P1, (b) site P2, and (c) site P3 during June-November 2018 period. Note that the VHG values become more positive as going from June, 2018 through November, 2018. Circled VHG values in (b) were deemed suspicious due to clogging of piezometer P2D.

$1336 \times 812 \mathrm{~mm}(96 \times 96$ DPI) 

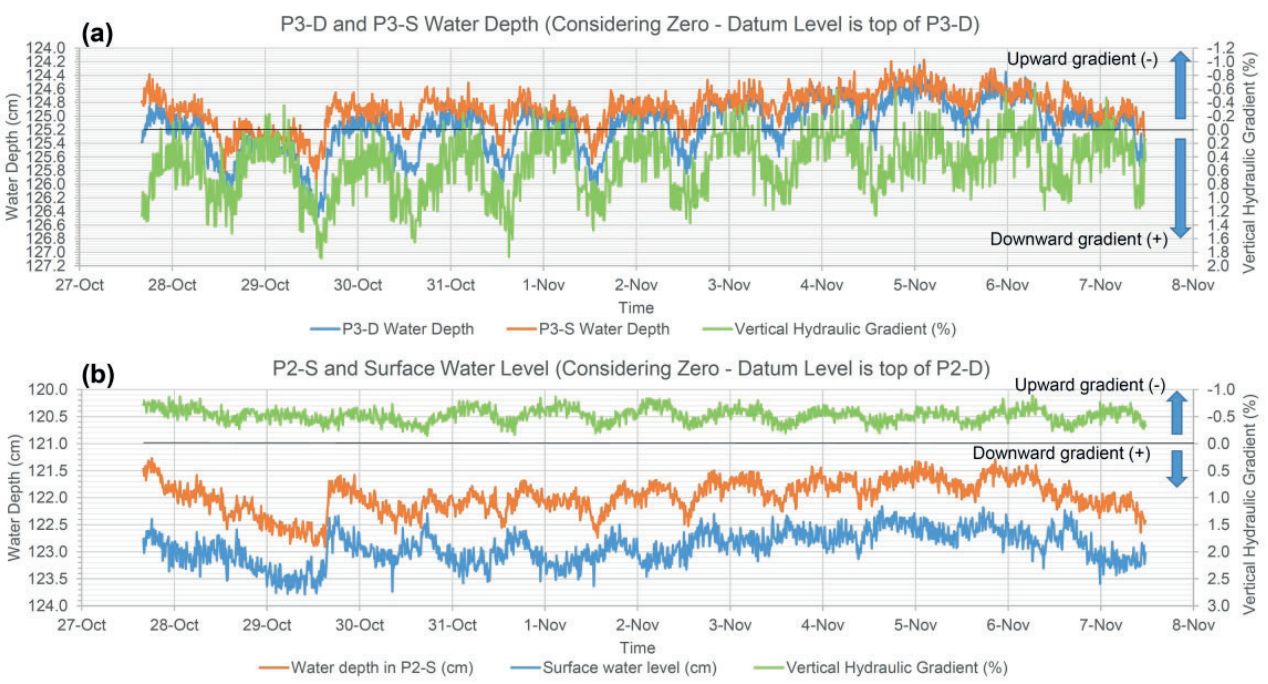

Figure 10 Water level measurements using pressure transducers (HOBO) and vertical hydraulic gradient values at (a) Site P3 and (b) Site P2 during 27-October-2018 to 7-November-2018 period.

$1116 \times 597 \mathrm{~mm}(120 \times 120 \mathrm{DPI})$ 
(a)

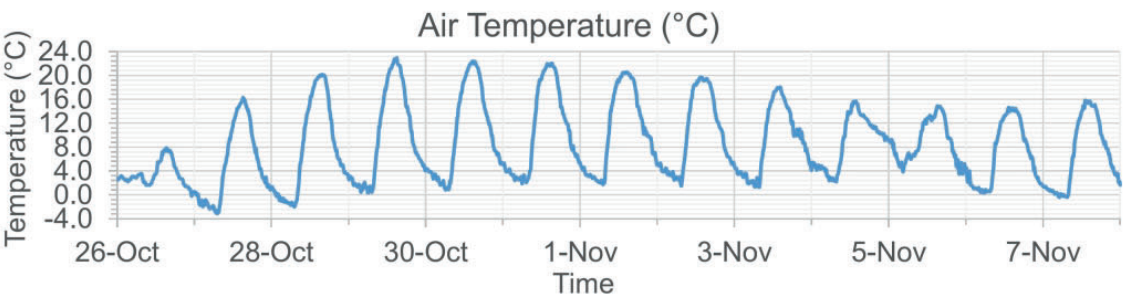

(b)

P3 Raw Time Series

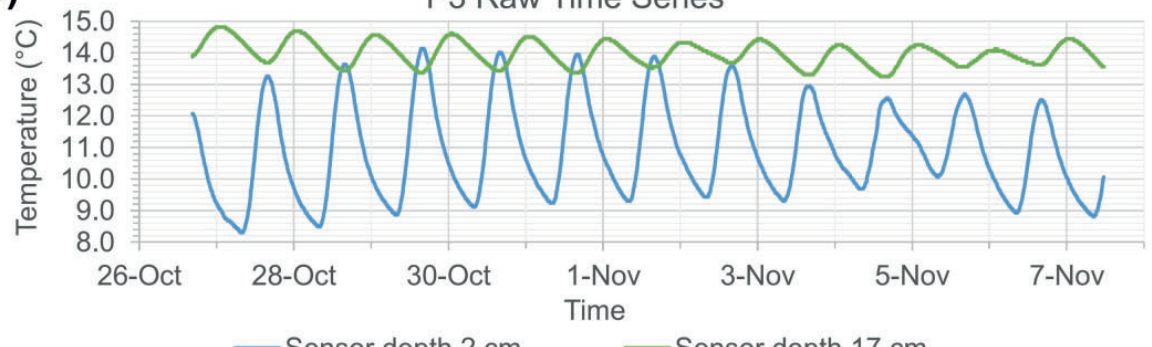

(c)

- Sensor depth $2 \mathrm{~cm} \quad$ - Sensor depth $17 \mathrm{~cm}$

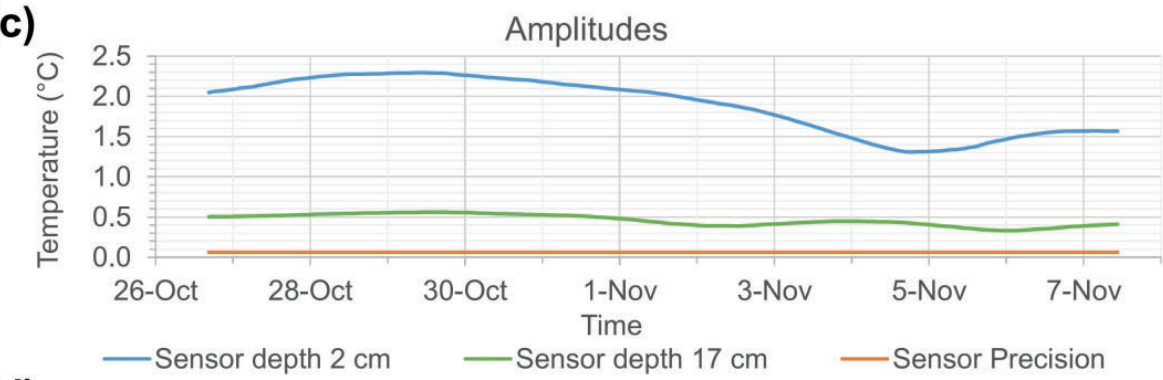

(d)

—Sensor depth $2 \mathrm{~cm} \quad$-Sensor depth $17 \mathrm{~cm} \quad$ - Sensor Precision

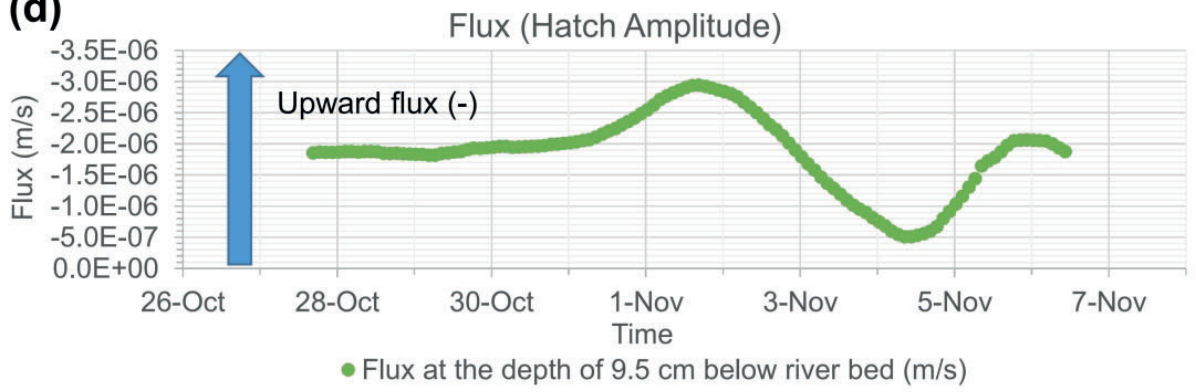

Figure 11 (a) Air temperature, (b) raw temperature data series, (c)amplitude variation and (d) estimated vertical flux values at site P3 for the 26-October-2018 to 7-November-2018 measurement period.

$$
831 \times 1048 \mathrm{~mm}(96 \times 96 \mathrm{DPI})
$$



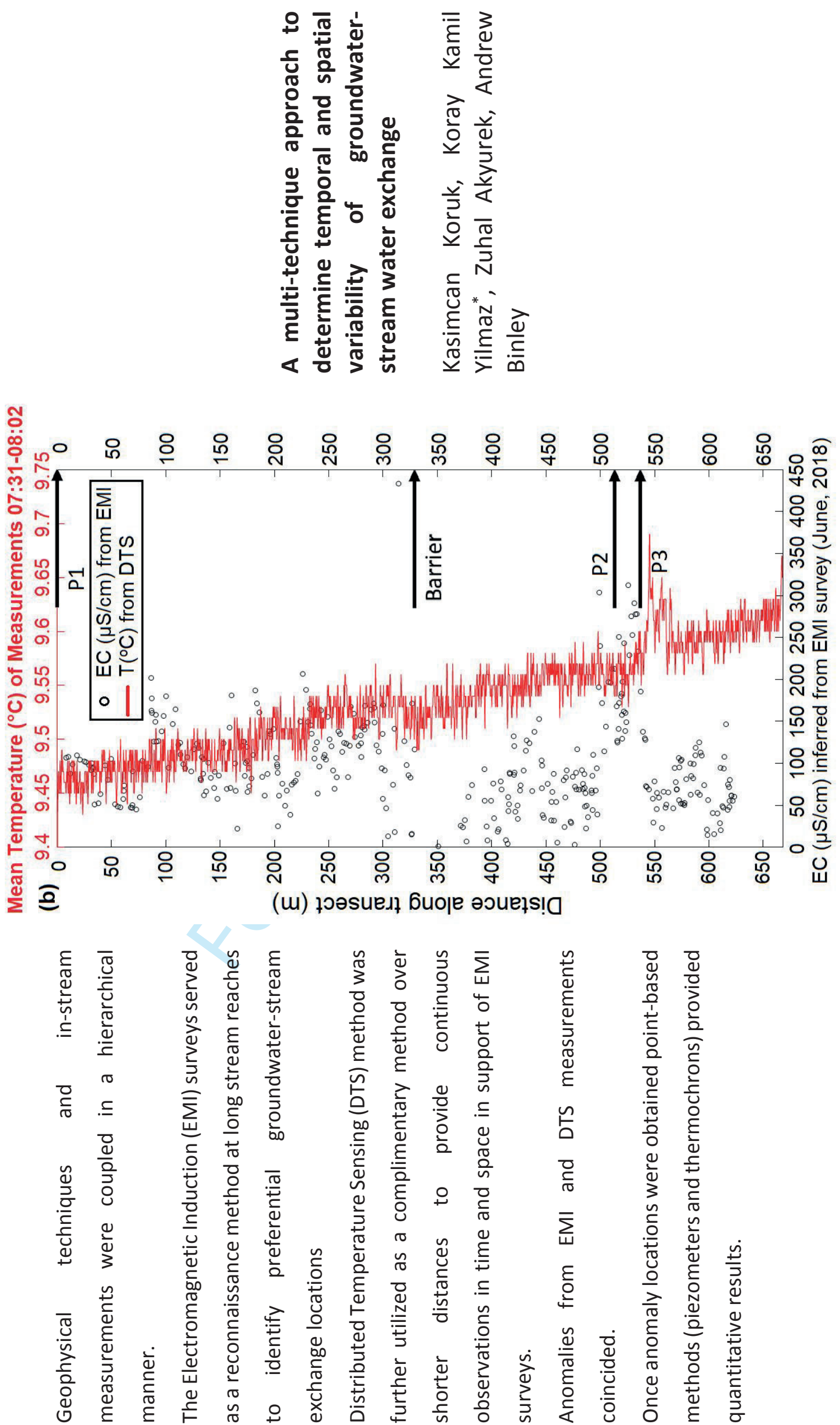

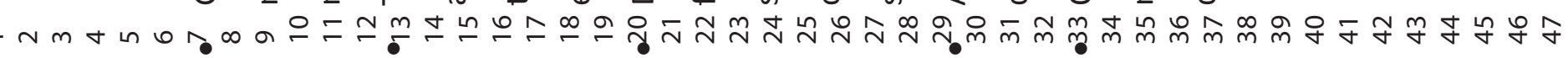

